\title{
Effects of Contamination and Cleaning on Parachute Structural Textile Elements
}

\author{
Catherine Mollmann ${ }^{1}$ \\ Airborne Systems North American, Pennsauken, NJ, 08109
}

\begin{abstract}
Throughout their lifecycle, parachute textiles come into contact with various other substances. This contact may occur during manufacturing and repair, storage and transportation, packing, or actual use. While this interaction does not always result in negative repercussions, it may cause a loss in material strength. This paper examines the strength degradation due to several contaminants as well as the effects of cleaning agents on common parachute materials. Materials tested were: Kevlar ${ }^{\circledR}$ cord and webbing, Nylon broadcloth and webbing, and Vectran ${ }^{\circledR}$ cord; all of these constitute the major structural elements for CPAS (Capsule Parachute Assembly System), the parachute system for the NASA Orion Crew Module. Contaminants tested were: sewing machine oil, dried stamping ink, dirt, basting glue, Sergene, and rust. Recommendations for cleaning (or not cleaning) these materials with respect to each of the contaminants are given in this paper, as well as recommendations for future tests.
\end{abstract}

\section{Nomenclature}

CPAS = Capsule Parachute Assembly System

EFT-1 = Exploration Flight Test 1

GMIP = Government Mandatory Inspection Point

\section{Introduction}

$\mathrm{P}$ ior to installation on the Exploration Flight Test 1 (EFT-1) test vehicle, the parachutes in the Orion Capsule Parachute Assembly System (CPAS) were examined with regard to several requirements, including cleanliness. During the post-manufacturing Government Mandatory Inspection Point (GMIP) process, 28 instances of contamination on main parachute Nylon broadcloth were discovered and recorded. The primary source identified for this contamination was sewing machine oil encountered during manufacturing.

As well as during manufacturing, contamination could potentially occur during packing, rigging, testing, recovery, etc. Contamination poses two major potential problems: (1) the contaminant may outgas during the mission while in space and/or (2) the contaminant may degrade the parachute materials. In order to quantify the effects of the latter, a study was conducted with various materials, contaminants, and cleaning agents.

A separate test campaign was also completed to quantify the strength degradation effects of rust on Nylon broadcloth, as well as to determine a possible cleaning regimen. This was completed in response to rust inadvertently developing on parachutes while they were being cleaned and repaired. While similar test methods were implemented for this study, the details and results are documented in a separate section of this paper.

\section{Test Program}

\section{A. Test Objectives}

The objective of this test program was to identify major sources of contamination that parachute canopies and components might encounter during their lifecycle. After all contaminants were identified, potential cleaning agents were identified. These contaminant-cleaning agent pairs were applied to different materials and the effect on breaking strength was determined through tensile testing. When a test resulted in appreciable strength degradation, the test was repeated with a higher quantity of samples and with more attention to detail in order to confirm results. Based on

\footnotetext{
${ }^{1}$ Production Engineer, Engineering, 5800 Magnolia Ave, Pennsauken, NJ, 08109, AIAA Member.
} 
results from both the initial testing and selected re-tests, cleaning agents and cleaning processes for each contaminant are recommended.

\section{B. Test Samples}

The effects of contamination on five materials, comprising the majority of the structural elements on CPAS, were examined. Table 1 details the materials tested. As the initial tests and the re-tests were completed at different times, different lots of materials had to be used for 3 of the 5 materials. For those 3 cases, materials with identical or very similar types of construction and strength-to-weight ratios were used.

Table 1. Test Sample Material and Specifications

\begin{tabular}{|c|c|c|c|c|c|c|}
\hline Material & Test & $\begin{array}{l}\text { Cage } \\
\text { Code }\end{array}$ & Specification & $\begin{array}{l}\text { Minimum } \\
\text { Strength }\end{array}$ & $\begin{array}{c}\text { Airborne } \\
\text { Lot } \\
\text { Number }\end{array}$ & $\begin{array}{c}\text { Typical } \\
\text { Parachute } \\
\text { Use }\end{array}$ \\
\hline Kevlar® Cord & $\begin{array}{l}\text { Initial and } \\
\text { Re-test }\end{array}$ & 05QR4 & 149000 Type IX & $2000 \mathrm{lbf}$ & 322132 & $\begin{array}{l}\text { Suspension } \\
\text { Line }\end{array}$ \\
\hline \multirow{2}{*}{$\begin{array}{l}\text { Kevlar® } \\
\text { Webbing }\end{array}$} & Initial & \multirow{2}{*}{ 1HHQ4 } & $\begin{array}{c}\text { PIA-T-87130 Type } \\
\text { X, Class } 3\end{array}$ & $2500 \mathrm{lbf}$ & 314654 & \multirow{2}{*}{ Radial } \\
\hline & Re-test & & $\begin{array}{l}\text { PIA-T-87130 Type } \\
\text { VI, Class } 5\end{array}$ & $1500 \mathrm{lbf}$ & 311566 & \\
\hline $\begin{array}{c}\text { Nylon } \\
\text { Broadcloth }\end{array}$ & $\begin{array}{l}\text { Initial and } \\
\text { Re-test }\end{array}$ & 05QR4 & 190026 & $34 \mathrm{lbf} /$ in & 331692 & $\begin{array}{l}\text { Ring/Sail } \\
\text { Panel }\end{array}$ \\
\hline \multirow{2}{*}{$\begin{array}{c}\text { Nylon } \\
\text { Webbing }\end{array}$} & Initial & \multirow{2}{*}{ 1HHQ4 } & \multirow{2}{*}{$\begin{array}{c}\text { PIA-W-4088 Type } \\
\text { XVII, Class } 1\end{array}$} & \multirow{2}{*}{$2500 \mathrm{lbf}$} & 330929 & \multirow{2}{*}{$\begin{array}{l}\text { Ribbon and } \\
\text { Vent Band }\end{array}$} \\
\hline & Retest & & & & 310359 & \\
\hline \multirow{2}{*}{$\begin{array}{l}\text { Vectran }{ }^{\circledR} \\
\text { Cord }\end{array}$} & Initial & \multirow{2}{*}{ 9N061 } & 101516-1050 & $1050 \mathrm{lbf}$ & 333698 & \multirow{2}{*}{ Vent Hoop } \\
\hline & Retest & & 101516-1600 & $1600 \mathrm{lbf}$ & 349581 & \\
\hline
\end{tabular}

To properly interface with the test equipment detailed later in Section II.E, each set of samples was prepared as detailed in Table 2:

Table 2. Test Sample Preparation

\begin{tabular}{|c|c|c|}
\hline Material & $\begin{array}{l}\text { Sample Cut } \\
\text { Length }\end{array}$ & Other Notes \\
\hline Kevlar® Cord & $56 "$ & $\begin{array}{l}4.00 " \text { flat loop with } 8.00 " \\
\text { insertions (see Figure 1) }\end{array}$ \\
\hline Kevlar ${ }^{\circledR}$ Webbing & $64 ”$ & -- \\
\hline Nylon Broadcloth & $36 "$ & $\begin{array}{l}\text { Unraveled to } 1.50 " \text { or } 2.00 " \\
\text { width per ASTM D 5035-06 }\end{array}$ \\
\hline Nylon Webbing & $64 "$ & -- \\
\hline Vectran ${ }^{\circledR}$ Cord & $56 ”$ & $\begin{array}{l}4.00 " \text { flat loop with } 8.00 " \\
\text { insertions (see Figure 1) }\end{array}$ \\
\hline
\end{tabular}

Further construction details of the Kevlar and Vectran cord samples are shown in Figure 1:

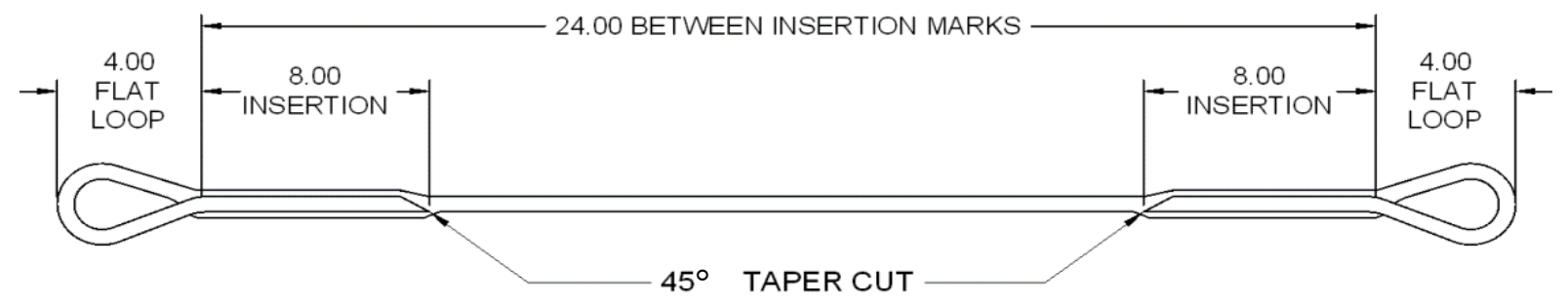

Figure 1. Standard Cord Sample Configuration 


\section{Contaminants and Cleaning Agents}

There are many sources of contamination for parachutes and related assets. The five examined in this testing program are listed below (rust is not included here, as it is discussed in a later section):

1. Sewing machine oil: oil is used on sewing machines and may be encountered during manufacturing or repair

2. Dried stamping ink: ink is used to mark parachutes and other components with identification information. Sometimes ink is applied incorrectly and needs to be removed

3. Dirt: parachutes are typically tested in the desert and come into contact with the (dirt) desert after landing

4. Basting glue: basting glue is used to hold two or more components together prior to sewing, particularly webbing. It is similar to glue from a craft-hot glue gun

5. Sergene: Sergene is used during manufacturing in order to prevent any cut and exposed ends from fraying. After initial application, Sergene dries as a hard substance. Sergene is typically only used on Kevlar®.

The first column in Table 3 below lists the contaminants from the above list. The second column shows cleaning agents that were used to attempt to remove each of the contaminants. Note that for some contaminants, such as stamping ink, more than one possible cleaning agent has been identified:

Table 3. Contaminant-Cleaning Agent Pairs

\begin{tabular}{|c|c|}
\hline Contaminant & Cleaning Agent \\
\hline Sewing Machine Oil & EverBlum \\
\hline \multirow{2}{*}{ Dried Stamping Ink } & EverBlum \\
\cline { 2 - 2 } & Ink Thinner \\
\hline \multirow{2}{*}{ Dirt } & Castile soap \\
\cline { 2 - 2 } & Dove® soap \\
\cline { 2 - 2 } & Woolite ${ }^{\circledR}$ \\
\hline Basting Glue & Isopropyl Alcohol \\
\hline Sergene & Rag \\
\hline
\end{tabular}

Each contaminant and cleaning agent is further detailed in Table 4:

Table 4. Contaminants and Cleaning Agents

\begin{tabular}{|c|c|c|}
\hline Name & Manufacturer & Detailed Description \\
\hline Sewing Machine Oil & E\&G Sales & Sewing Machine Oil \\
\hline Stamping Ink & Vision Marking Devices & A-A-59291 Type I, Blue \\
\hline Dirt & -- & YPG Drop Zone Dirt \\
\hline Basting Glue & $3 \mathrm{M}$ & $\begin{array}{c}3 \mathrm{M}^{\text {TM }} \text { Scotch-Weld } \\
\text { TM Hot Melt Adhesive }\end{array}$ \\
\hline Sergene & $\begin{array}{c}\text { General Plastics } \\
\text { Corporation }\end{array}$ & Sergene \\
\hline EverBlum & Universal Sewing Supply & Premium Cleaning Fluid \\
\hline Ink Thinner & Vision Marking Devices & Ink Thinner \\
\hline Castile & Dr. Bronner’s & Unscented Mild Pure Castile Soap \\
\hline Dove $\circledR$ & Unilever & Dove ${ }^{\circledR ~ S e n s i t i v e ~ S k i n ~ U n s c e n t e d ~ S o a p ~}$ \\
\hline Woolite ${ }^{\circledR}$ & Bissell Homecare & Woolite ${ }^{\circledR}$ Fabric and Upholstery Cleaner \\
\hline Isopropyl Alcohol & Vision Marking Devices & Isopropyl Alcohol \\
\hline
\end{tabular}




\section{Preparation of Test Samples (for Initial Tests)}

For the initial tests, each of the cells in Table 3 represents a different set of 5 samples. For example, 5 samples were contaminated with sewing machine oil and 5 samples were contaminated with sewing machine oil and then cleaned with EverBlum. Counting the number of cells, this means that 13 sets of samples, or $13 * 5=65$ total samples, were initially prepared for each material type. In addition, 5 controls (with no contamination or cleaning agent applied) were tested. These controls were required in order to establish the base material strength which was then compared to the strength of both the contaminated and the cleaned samples.

During the application of the contaminants and cleaning agents, different containers and methods were used to store and apply them to the materials. For sewing machine oil, stamping ink, Sergene, EverBlum, ink thinner, and isopropyl alcohol, a standard $16 \mathrm{oz}$ plastic squeeze bottle with a standard nozzle (McMaster-Carr P/N 4176T6) was used. See Figure 2. This bottle was used to evenly apply contaminants and cleaning agents to the samples. Dirt, taken from Yuma Proving Grounds in Yuma, Arizona, was stored in a plastic bag and applied by hand. Basting glue was applied to the samples using a hot-glue gun.

Woolite ${ }^{\circledR}$ was sprayed directly on the materials and then applied to the material with a wet sponge. Dove ${ }^{\circledR}$ and Castile soaps were mixed with warm water and a sponge was used to apply them to the contaminated samples. All of the other cleaning agents were spread and applied using a lint-free rag. The rag or sponge was applied firmly to each of the materials, yet care was taken to avoid breaking fibers and damaging the materials.

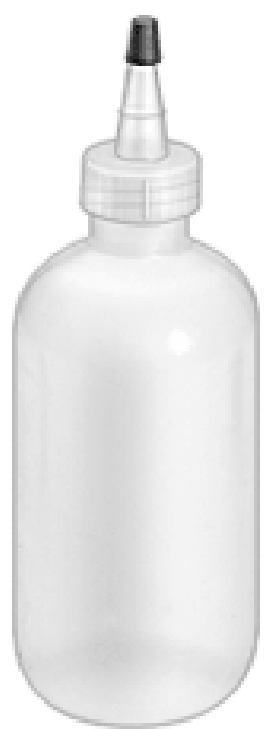

Figure 2. Plastic Squeeze Bottle

\section{Controls}

For each material type, 5 controls were tested. These controls were constructed as detailed in Section II.B. Care was taken to prevent any contact between the controls and the contaminants/cleaning agents.

\section{Sewing Machine Oil}

For each material type, 10 samples were contaminated with a line of sewing machine oil (see Figure 3). Approximately the same amount of sewing machine oil was applied to each sample using the plastic squeeze bottle shown in Figure 2. Figure 3 below shows Kevlar ${ }^{\circledR}$ webbing contaminated with sewing machine oil. When the sewing machine oil dried, EverBlum was used to remove the contaminant on 5 of the 10 samples (see Figure 4).

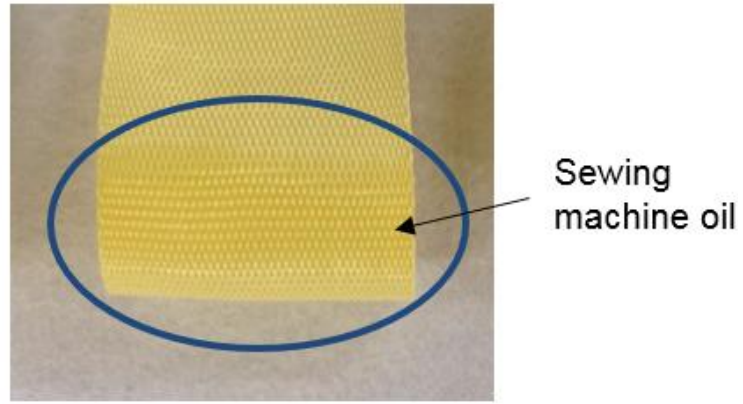

Figure 3. Kevlar ${ }^{\circledR}$ Webbing Contaminated with Sewing Machine Oil

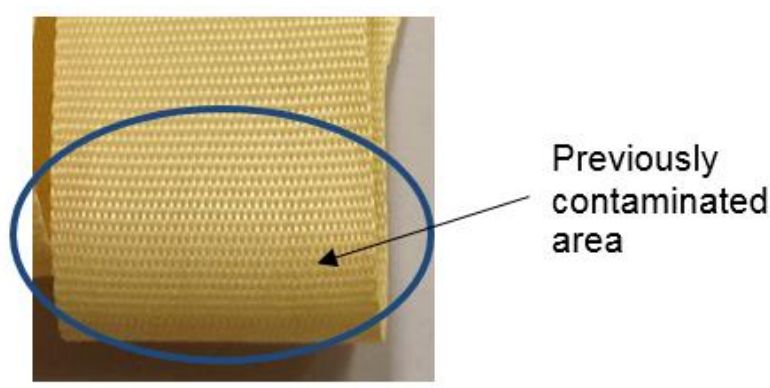

Figure 4. Kevlar ${ }^{\circledR}$ Webbing Contaminated with Sewing Machine Oil and Cleaned with EverBlum 


\section{Dried Stamping Ink}

For each material type, 15 samples were contaminated with a line of stamping ink (see Figure 5). Approximately the same amount of stamping ink was applied to each sample using the plastic squeeze bottle shown in Figure 2. When the stamping ink dried, EverBlum was used to clean 5 of the samples (see Figure 6). A lint-free rag was used to lightly scrub the materials. Ink thinner was used to remove the contaminant on 5 of the samples (see Figure 7). A lint-free rag was also used to scrub the materials.

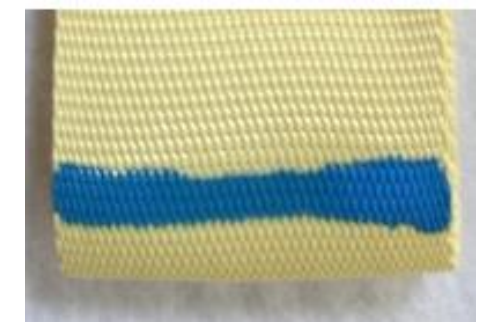

Figure 5. Kevlar ${ }^{\circledR}$ Webbing Contaminated with Stamping Ink

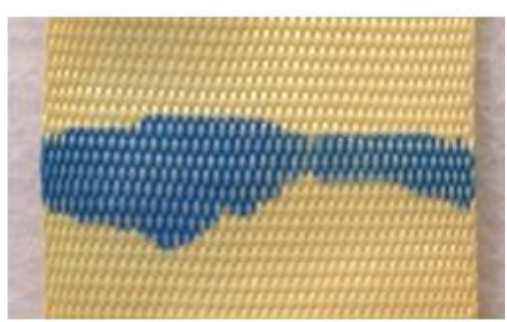

Figure 6. Kevlar® Webbing Contaminated with Stamping Ink and Cleaned with EverBlum

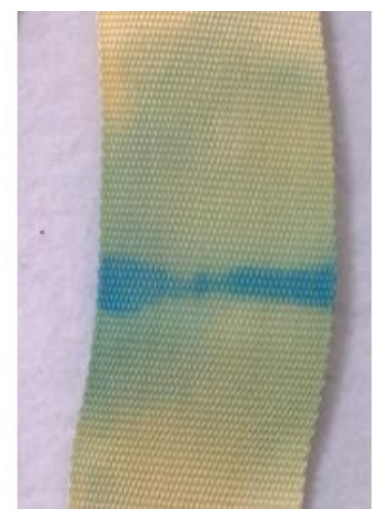

Figure 7. Kevlar® Webbing Contaminated with Stamping Ink and Cleaned with Ink Thinner

\section{Dirt}

For each material type, 20 samples were contaminated with dirt (see Figure 8). Approximately the same amount of dirt was manually applied to each sample to thoroughly rub in the dirt. Woolite ${ }^{\circledR}$ was used to remove the dirt from 5 samples of each material type (see Figure 9). Woolite ${ }^{\circledR}$ was applied to the materials using a spray can and the material was lightly scrubbed with a wet sponge. Dove ${ }^{\circledR}$ soap and warm water were used to remove the dirt from 5

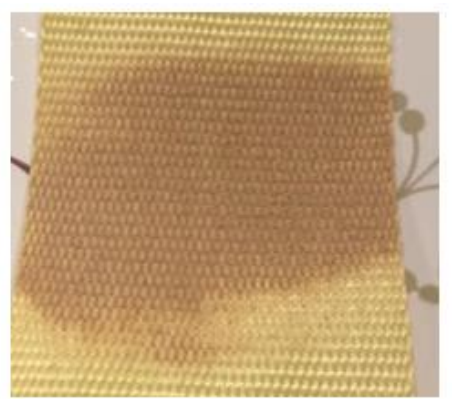

Figure 8. Kevlar® Webbing Contaminated with Dirt

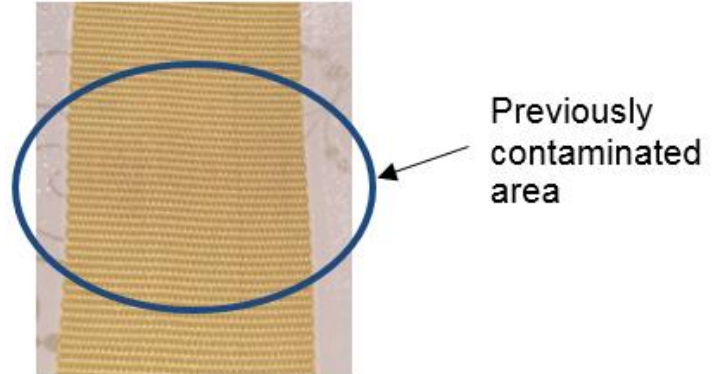

Figure 9. Kevlar ${ }^{\circledR}$ Webbing Contaminated with Dirt and Cleaned with Woolite ${ }^{\circledR}$ 


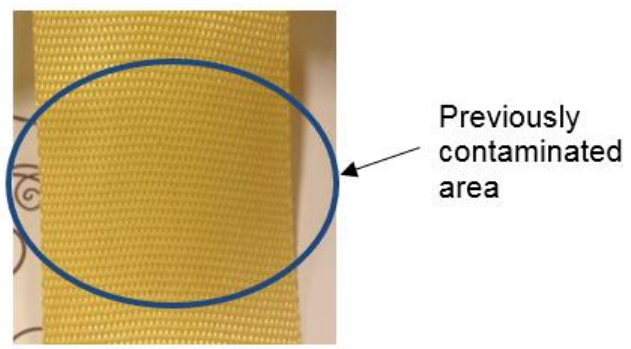

Figure 10. Kevlar ${ }^{\circledR}$ Webbing Contaminated with Dirt and Cleaned with Dove ${ }^{\circledR}$

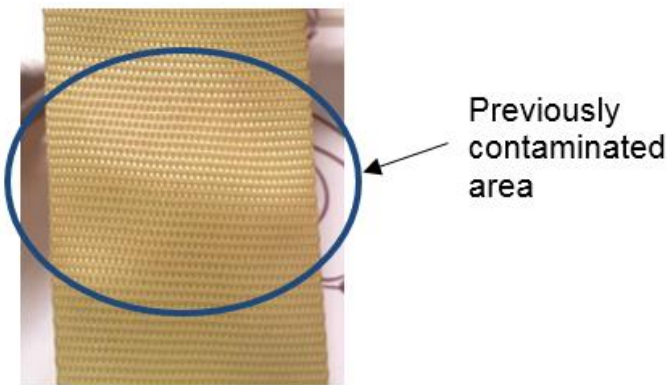

Figure 11. Kevlar® Webbing Contaminated with Dirt and Cleaned with Castile

more samples (see Figure 10). The Dove ${ }^{\circledR}$ soap was mixed with warm water and a lint-free rag was used to apply the cleaning agent to the materials. Castile soap and warm water was used to remove the dirt from 5 samples of each material type (see Figure 11). The Castile soap was mixed with warm water and a lint-free rag was used to apply the cleaning agent to the materials.

\section{Basting Glue}

For each material, 10 samples were contaminated with a line of basting glue (see Figure 12) using a hot glue gun. After the basting glue dried, the sample was cleaned with isopropyl alcohol. A small amount of isopropyl alcohol was initially applied to the material; after sitting for about a minute, the line of basting glue was carefully peeled off. A lint-free rag, saturated with isopropyl alcohol, was then used to remove the remainder of the basting glue. Care was taken to avoid damaging fibers during cleaning. See Figure 13.

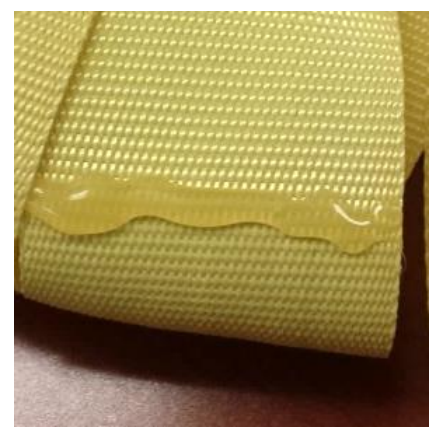

Figure 12. Kevlar® Webbing Contaminated with Basting Glue

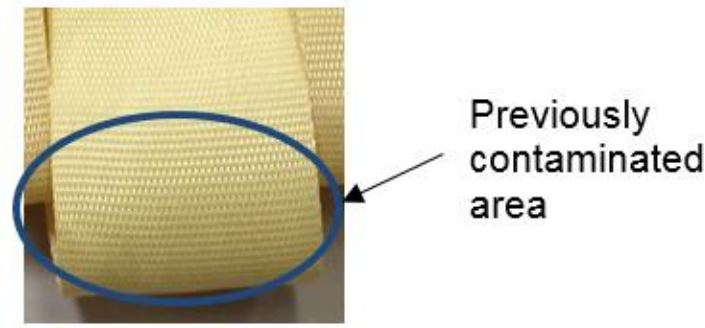

Figure 13. Kevlar ${ }^{\circledR}$ Webbing Contaminated with Basting Glue and Cleaned with Isopropyl Alcohol 


\section{Sergene}

10 samples of each material were contaminated with a line of Sergene (see Figure 14) using the plastic squeeze bottle shown in Figure 2. After applying Sergene to a sample, a lint-free rag was used to soak up as much Sergene as possible (see Figure 15). This was done for 5 samples per material type. After removing as much Sergene as possible, the samples were allowed to dry.

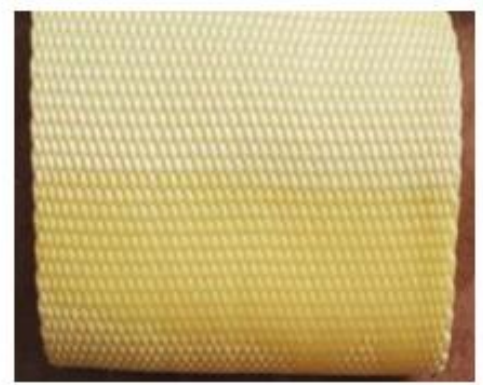

Figure 14. Kevlar ${ }^{\circledR}$ Webbing Contaminated with Sergene

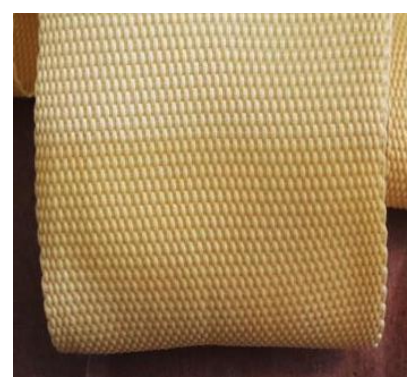

Figure 15. Kevlar ${ }^{\circledR}$ Webbing Contaminated with Sergene and Cleaned with a Rag 


\section{Photos of Contaminated Samples}

Table 5 through Table 9 document representative photos of each of the material types after application of the contaminants:

Table 5. Appearance of Kevlar® Cord after Contamination

\begin{tabular}{|c|c|}
\hline Control & Representative Photo \\
\hline Mineral Oil & \\
\hline Ink & \\
\hline Basting Glue & \\
\hline Dirt & \\
\hline
\end{tabular}


Table 6. Appearance of Kevlar® Webbing after Contamination

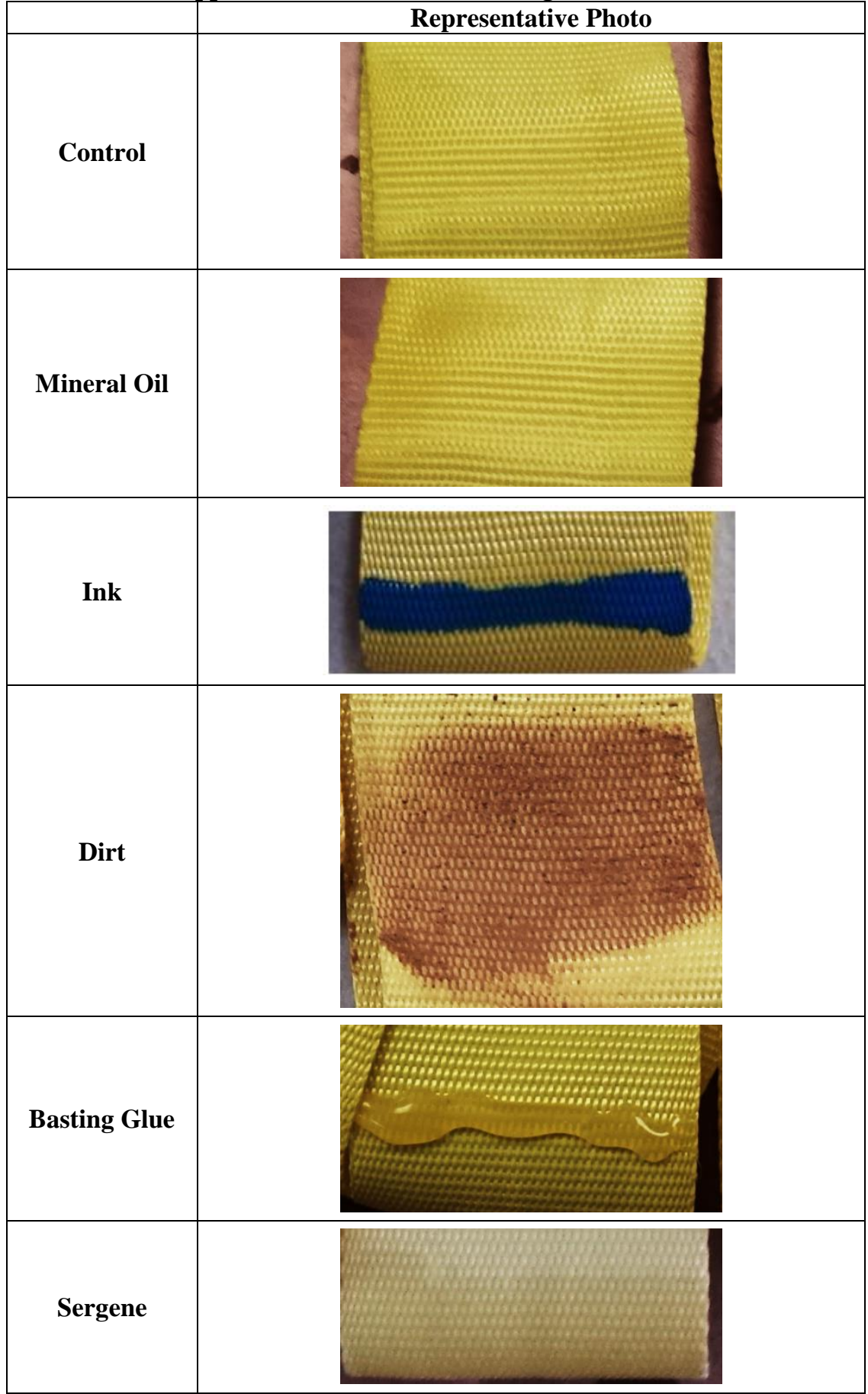


Table 7. Appearance of Nylon Broadcloth after Contamination

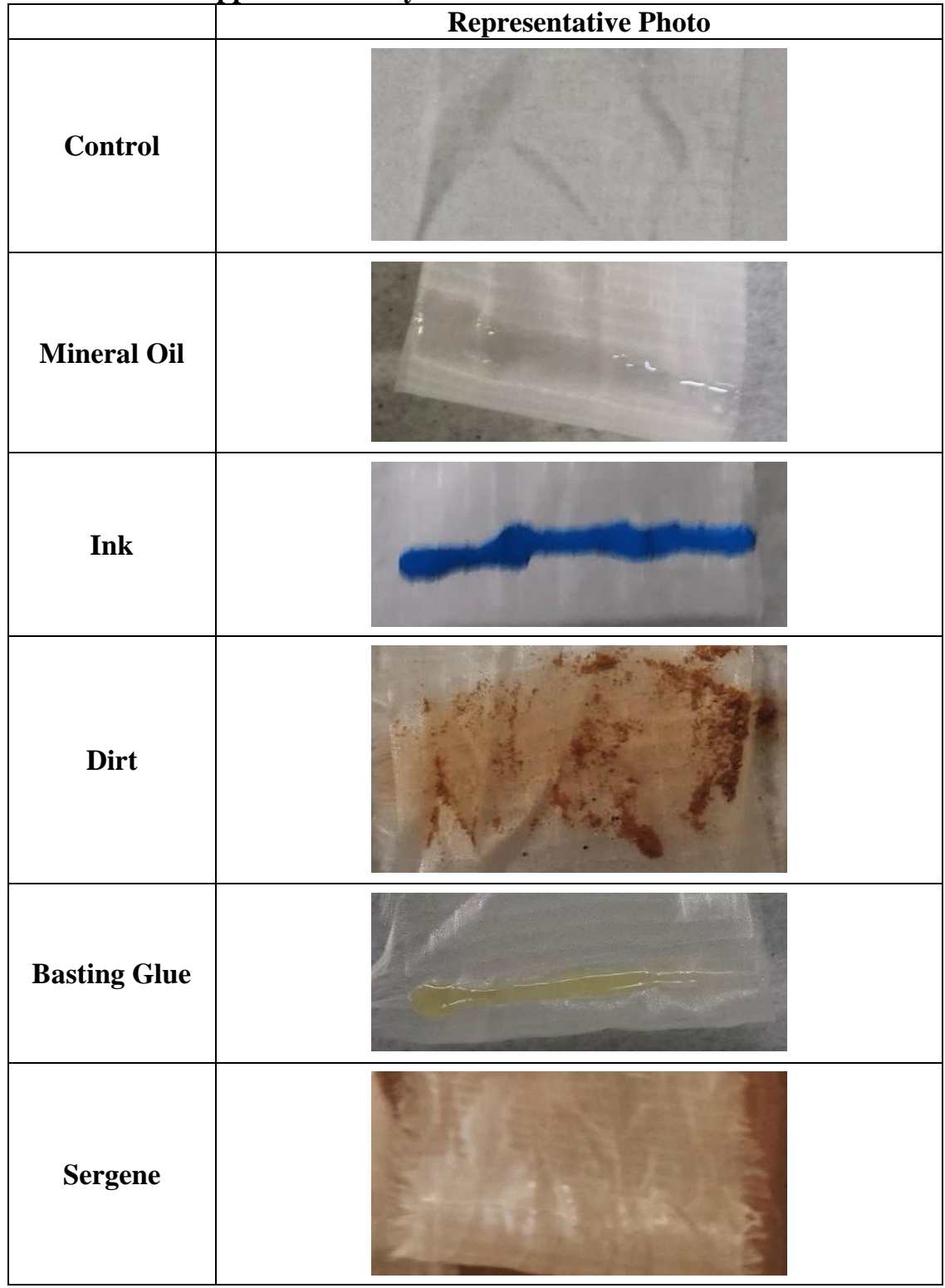


Table 8. Appearance of Nylon Webbing after Contamination

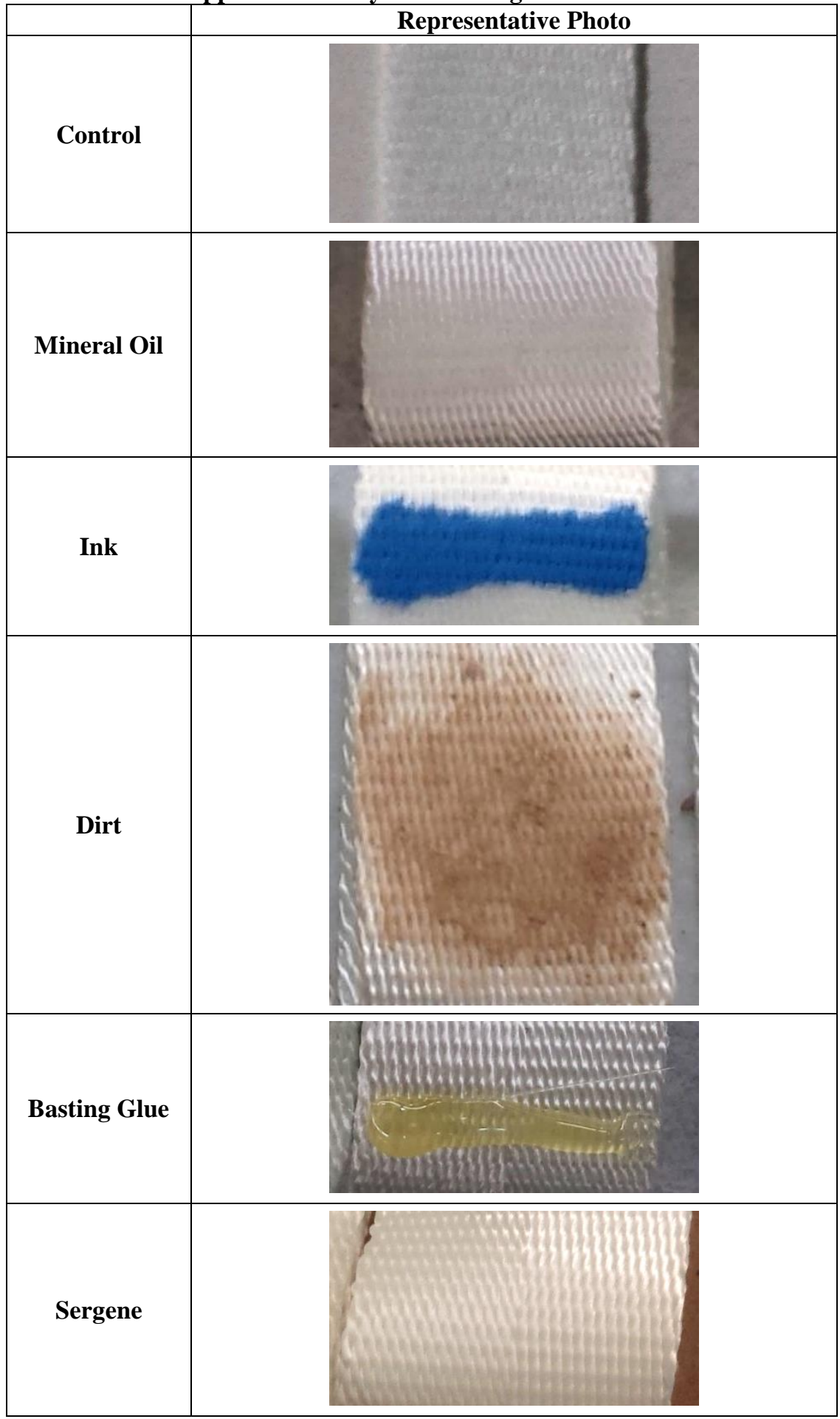


Table 9. Appearance of Vectran ${ }^{\circledR}$ Cord after Contamination

\begin{tabular}{|c|c|}
\hline Control & Representative Photo \\
\hline Mineral Oil & \\
\hline Ink & \\
\hline Sergene & \\
\hline Birt & \\
\hline
\end{tabular}




\section{E. Testing}

\section{Test Equipment}

Two different tensile testing machines were used to break the samples to failure. A machine with a 30,000 lb capacity, the 30k Tinius Olsen, was used to break the samples constructed with Kevlar ${ }^{\circledR}$ cord, Kevlar ${ }^{\circledR}$ webbing, Nylon webbing, and Vectran ${ }^{\circledR}$ cord. A machine with a 5,000 lb capacity, the 5k Tinius Olsen, was used to break the samples constructed with Nylon broadcloth.

\section{Webbing Set-Up}

Both Kevlar® and Nylon webbing samples were tested on the 30k Tinius Olsen using the double Sedam grips. Figure 16 shows a side view of the test setup, showing how the webbing is routed. The black lines represent the route of the webbing and the shaded portions show the cross-section of the Sedam grips.

Figure 17 shows an example of a Kevlar® webbing sample installed in the fixture and ready to be tested. Care was taken to ensure that the sample was positioned in the middle of the grips. Once the test was started, the bottom grip moved downward at $3 \mathrm{in} / \mathrm{min}$ until the sample broke. This loads up the webbing and forces the Sedam grips to engage the material.

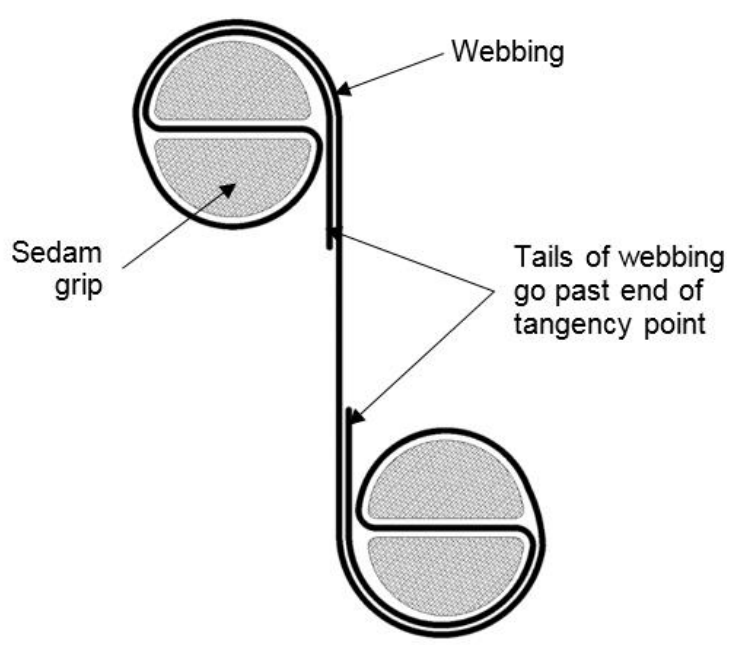

Figure 16. Webbing Routing

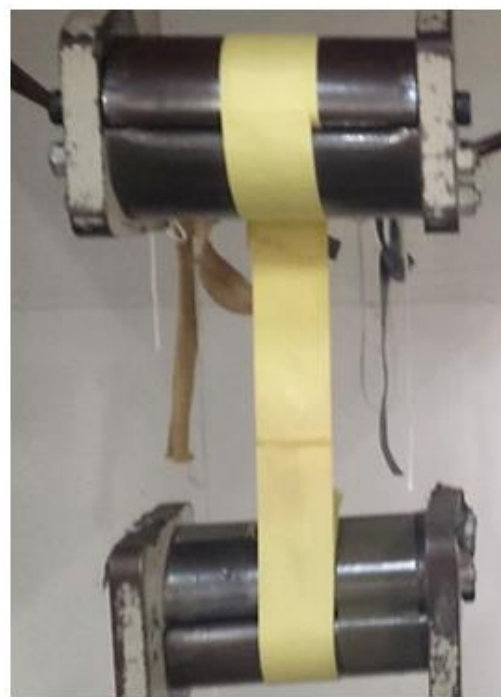

Figure 17. Kevlar ${ }^{\circledR}$ Webbing Sample Ready to Test 


\section{Cord Set-Up}

Both Kevlar ${ }^{\circledR}$ and Vectran ${ }^{\circledR}$ cord samples were tested on the 30k Tinius Olsen using the double-pin grips. Figure 18 below is a front view of the test setup, showing how the cord routed along the pins. The black lines represent the path of the cord and the shaded portions show the position of the double-pin grips. Care was taken to ensure that the cord was not twisted over its length.

Figure 19 shows an example of a Kevlar ${ }^{\circledR}$ cord sample installed in the fixture and ready to be tested. Once the test was started, the bottom double-pin moved downward at $3 \mathrm{in} / \mathrm{min}$.

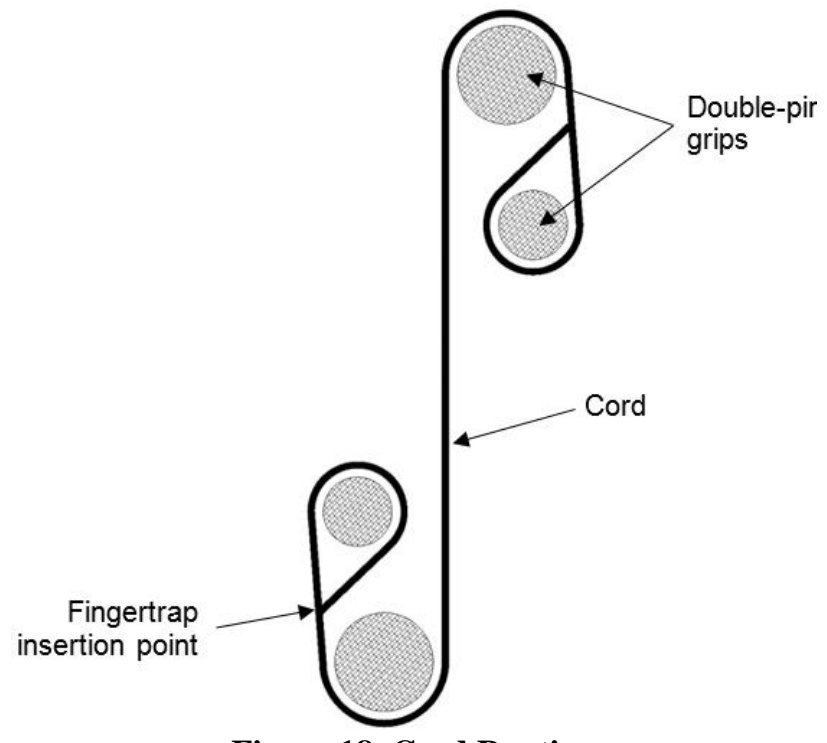

Figure 18. Cord Routing

\section{Broadcloth Set-Up}

The Nylon broadcloth samples were tested on the 5k Tinius Olsen machine using double Sedam grips. The broadcloth was routed as seen in Figure 16. Figure 20 shows an example of a Nylon broadcloth sample installed in the fixture and ready to be tested. Care was taken to ensure that the sample was positioned in the middle of the grips. Once the test was started, the top grip moved upward at $3 \mathrm{in} / \mathrm{min}$ until the sample broke.

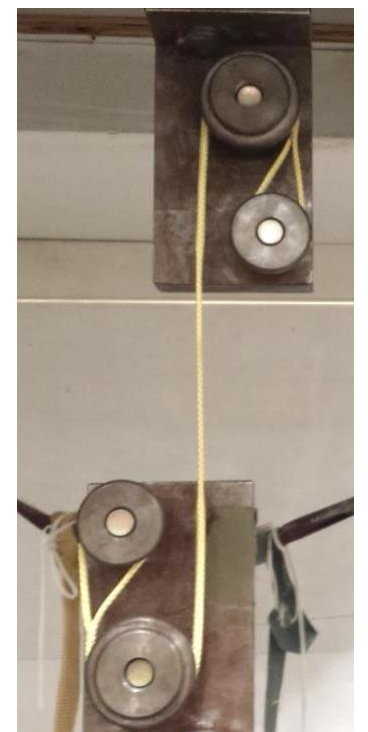

Figure 19. Kevlar ${ }^{\circledR}$ Cord Sample Ready to Test

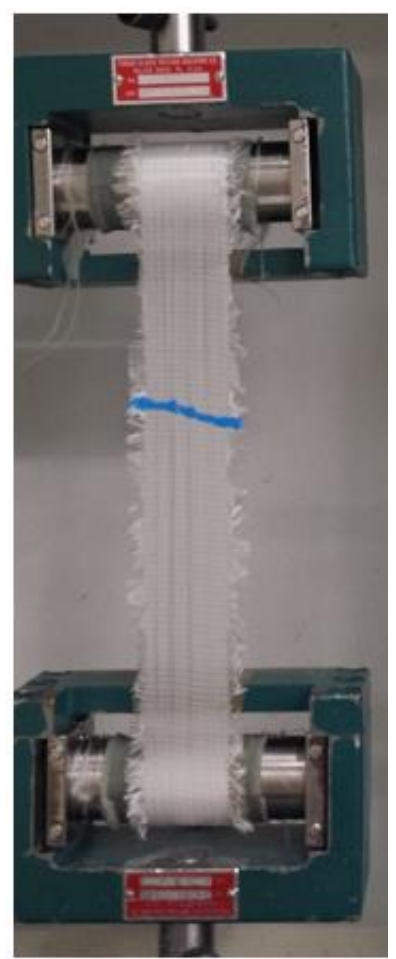

Figure 20. Nylon Broadcloth Sample Ready to Test 


\section{Initial Test Results}

\section{A. Strength Degradation}

Each initial sample set consisted of 5 controls, 5 contaminated samples, and 5 contaminated-then-cleaned samples. Therefore, two efficiencies were calculated: one to compare the controls to the contaminated samples and another to compare the controls to the contaminated-then-cleaned samples.

Two types of efficiencies were calculated for each set of samples. The first, the mean efficiency, is calculated by Equation 1:

$$
\text { Mean Efficiency }=\frac{\text { Average sample breaking strength }}{\text { Average control breaking strength } * \text { Number of plies }} * 100
$$

The number of plies is the number of layers between the two grips through which the load can be transferred; for these tests, the number of plies is always one, so the mean efficiency is a ratio of the sample breaking strength to the control breaking strength.

A more conservative way to access the degradation effects is through the standard efficiency, as calculated in Equation 2:

$$
\text { Standard Ef ficiency }=\frac{(\text { Average-standard deviation })_{\text {sample breaking strength }}}{\text { Average control breaking strength } * \text { Number of plies }} 100
$$

The standard efficiency will always be equal to or less than the mean efficiency, as it introduces a smaller value in the numerator. For these sets of tests, the small number of samples (5) leads to a potentially large standard deviation that could artificially lower the standard efficiency and possibly indicate unreal effects. Therefore, the mean efficiency was used to analyze the results and give recommendations.

Table 10 below gives the mean efficiencies from all of the initial tests. Those tests that resulted in mean efficiencies less than $95 \%$ are highlighted in red:

Table 10. Mean Efficiencies, Initial Testing

\begin{tabular}{|c|c|c|c|c|c|}
\hline & $\begin{array}{c}\text { Kevlar® } \\
\text { Cord }\end{array}$ & $\begin{array}{c}\text { Kevlar }{ }^{\circledR} \\
\text { Webbing }\end{array}$ & $\begin{array}{c}\text { Nylon } \\
\text { Broadcloth }\end{array}$ & $\begin{array}{c}\text { Nylon } \\
\text { Webbing }\end{array}$ & $\begin{array}{c}\text { Vectran® } \\
\text { Cord }\end{array}$ \\
\hline Mineral Oil & $100 \%$ & $98 \%$ & $101 \%$ & $97 \%$ & $100 \%$ \\
\hline $\begin{array}{c}\text { Mineral Oil- } \\
\text { EverBlum }\end{array}$ & $99 \%$ & $101 \%$ & $101 \%$ & $98 \%$ & $101 \%$ \\
\hline Ink & $96 \%$ & $101 \%$ & $104 \%$ & $98 \%$ & $93 \%$ \\
\hline Ink-EverBlum & $94 \%$ & $94 \%$ & $101 \%$ & $100 \%$ & $95 \%$ \\
\hline Ink-Ink Thinner & $91 \%$ & $90 \%$ & $100 \%$ & $99 \%$ & $97 \%$ \\
\hline Dirt & $97 \%$ & $101 \%$ & $102 \%$ & $98 \%$ & $93 \%$ \\
\hline Dirt-Woolite ${ }^{\circledR}$ & $100 \%$ & $101 \%$ & $101 \%$ & $92 \%$ & $98 \%$ \\
\hline Dirt-Dove® & $95 \%$ & $100 \%$ & $98 \%$ & $81 \%$ & $92 \%$ \\
\hline Dirt-Castile & $98 \%$ & $102 \%$ & $98 \%$ & $85 \%$ & $93 \%$ \\
\hline Basting Glue & $101 \%$ & $97 \%$ & $103 \%$ & $102 \%$ & $90 \%$ \\
\hline Basting Glue- & $97 \%$ & $96 \%$ & $104 \%$ & $100 \%$ & $96 \%$ \\
\hline Isopropyl Alcohol & $95 \%$ & $102 \%$ & $103 \%$ & $99 \%$ & $99 \%$ \\
\hline Sergene & $93 \%$ & $98 \%$ & $101 \%$ & $101 \%$ & $99 \%$ \\
\hline Sergene-Rag & & & & \\
\hline
\end{tabular}


Since there was often no degradation to material strength after contamination, some mean efficiencies are slightly over $100 \%$. This signifies that the control average was very close to the sample average, but the variation in breaking values within each set was wide enough to result in a sample average greater than a control average.

Table 11 below gives all of the standard efficiencies from the initial tests. As stated above, these values are more conservative than the mean efficiencies and are not used to formulate the recommendations presented in this report:

Table 11. Standard Efficiencies, Initial Testing

\begin{tabular}{|c|c|c|c|c|c|}
\hline & $\begin{array}{c}\text { Kevlar } \\
\text { Cord }\end{array}$ & $\begin{array}{c}\text { Kevlar }{ }^{\circledR} \\
\text { Webbing }\end{array}$ & $\begin{array}{c}\text { Nylon } \\
\text { Broadcloth }\end{array}$ & $\begin{array}{c}\text { Nylon } \\
\text { Webbing }\end{array}$ & $\begin{array}{c}\text { Vectran } \\
\text { Cord }\end{array}$ \\
\hline Mineral Oil & $97 \%$ & $95 \%$ & $95 \%$ & $95 \%$ & $93 \%$ \\
\hline $\begin{array}{c}\text { Mineral Oil- } \\
\text { EverBlum }\end{array}$ & $97 \%$ & $98 \%$ & $99 \%$ & $96 \%$ & $98 \%$ \\
\hline Ink & $94 \%$ & $97 \%$ & $101 \%$ & $97 \%$ & $83 \%$ \\
\hline Ink-EverBlum & $90 \%$ & $88 \%$ & $100 \%$ & $100 \%$ & $89 \%$ \\
\hline Ink-Ink Thinner & $87 \%$ & $83 \%$ & $98 \%$ & $98 \%$ & $93 \%$ \\
\hline Dirt & $95 \%$ & $97 \%$ & $99 \%$ & $94 \%$ & $83 \%$ \\
\hline Dirt-Woolite ${ }^{\circledR}$ & $98 \%$ & $96 \%$ & $99 \%$ & $90 \%$ & $94 \%$ \\
\hline Dirt-Dove ${ }^{\circledR}$ & $92 \%$ & $97 \%$ & $97 \%$ & $77 \%$ & $86 \%$ \\
\hline Dirt-Castile & $94 \%$ & $94 \%$ & $95 \%$ & $84 \%$ & $85 \%$ \\
\hline Basting Glue & $100 \%$ & $93 \%$ & $101 \%$ & $100 \%$ & $80 \%$ \\
\hline $\begin{array}{c}\text { Basting Glue- } \\
\text { Isopropyl Alcohol }\end{array}$ & $94 \%$ & $94 \%$ & $103 \%$ & $98 \%$ & $88 \%$ \\
\hline Sergene & $93 \%$ & $100 \%$ & $101 \%$ & $98 \%$ & $97 \%$ \\
\hline Sergene-Rag & $89 \%$ & $95 \%$ & $99 \%$ & $99 \%$ & $97 \%$ \\
\hline
\end{tabular}

\section{B. Appearances of Material after Cleaning}

The appearance of the material after cleaning is included with the final results in Section V.B. 


\section{Differences between Mean and Standard Efficiencies}

Some of the efficiencies may have been low due to the nature of the material or testing program. Because there were only 5 controls and 5 samples being compared for each of the initial test sets, the differences between the mean and standard efficiencies were sometimes high. Table 12 shows this difference for each test. The closer the value is to zero, the more consistent the breaking values were. Values higher than 5\% are highlighted in red:

Table 12. Difference in Mean and Standard Efficiencies, Initial Results

\begin{tabular}{|c|c|c|c|c|c|}
\hline & $\begin{array}{c}\text { Kevlar } \\
\text { Cord }\end{array}$ & $\begin{array}{c}\text { Kevlar® } \\
\text { Webbing }\end{array}$ & $\begin{array}{c}\text { Nylon } \\
\text { Broadcloth }\end{array}$ & $\begin{array}{c}\text { Nylon } \\
\text { Webbing }\end{array}$ & $\begin{array}{c}\text { Vectran }{ }^{\circledR} \\
\text { Cord }\end{array}$ \\
\hline Mineral Oil & $3 \%$ & $3 \%$ & $6 \%$ & $2 \%$ & $7 \%$ \\
\hline $\begin{array}{c}\text { Mineral Oil- } \\
\text { EverBlum }\end{array}$ & $2 \%$ & $3 \%$ & $2 \%$ & $2 \%$ & $3 \%$ \\
\hline Ink & $2 \%$ & $4 \%$ & $3 \%$ & $1 \%$ & $10 \%$ \\
\hline Ink-EverBlum & $4 \%$ & $6 \%$ & $1 \%$ & $0 \%$ & $6 \%$ \\
\hline Ink-Ink Thinner & $4 \%$ & $7 \%$ & $2 \%$ & $1 \%$ & $4 \%$ \\
\hline Dirt & $2 \%$ & $4 \%$ & $3 \%$ & $4 \%$ & $10 \%$ \\
\hline Dirt-Woolite ${ }^{\circledR}$ & $2 \%$ & $5 \%$ & $2 \%$ & $2 \%$ & $4 \%$ \\
\hline Dirt-Dove ${ }^{\circledR}$ & $3 \%$ & $3 \%$ & $1 \%$ & $4 \%$ & $6 \%$ \\
\hline Dirt-Castile & $4 \%$ & $8 \%$ & $3 \%$ & $1 \%$ & $8 \%$ \\
\hline Basting Glue & $1 \%$ & $4 \%$ & $2 \%$ & $2 \%$ & $10 \%$ \\
\hline Basting Glue- & $3 \%$ & $2 \%$ & $1 \%$ & $2 \%$ & $8 \%$ \\
\hline Isopropyl Alcohol & $3 \%$ & $2 \%$ & $2 \%$ & $1 \%$ & $2 \%$ \\
\hline Sergene & $2 \%$ & $3 \%$ & $2 \%$ & $2 \%$ & $2 \%$ \\
\hline Sergene-Rag & $4 \%$ & $4.2 \%$ & $2.3 \%$ & $1.8 \%$ & $6.2 \%$ \\
\hline Average & $2.8 \%$ & & & & \\
\hline
\end{tabular}

As can be seen from the above testing data, Vectran ${ }^{\circledR}$ tends to have less precise breaking strengths, with an average difference between the mean and standard efficiencies of $6 \%$. Kevlar® has breaking strengths more precise (average difference of 3-4\%), and Nylon has very precise breaking strengths (average difference of $2 \%$ ). This effect is primarily due to the mechanical properties inherent to each of the material types and is typical of CPAS testing ${ }^{1}$. 


\section{Identification of Re-Tests}

Before any final recommendations were made, the initial results were used to identify re-tests. The goal of the retests were to more closely examine the effects of the contamination or cleaning, as the results may not be real or could be easily mitigated. There are a few reasons why the mean efficiencies may have been low for certain sample sets:

- Actual strength degradation occurred as a result of interaction with the contaminant or cleaning agent

- Actual strength degradation occurred due to the cleaning method (how vigorously the samples were cleaned), as the material fibers may have been broken

- The low number of samples, coupled with the spread of breaking values, resulted in a low efficiency

- The base material itself naturally had a large strength variation, even without any interaction with other substances

Sample sets with mean efficiencies less than $95 \%$ were chosen for re-tests; ones $95 \%$ or above were assumed to have experienced no actual appreciable strength degradation. See Table 13 for the identified re-tests:

Table 13. Chosen Re-Tests

\begin{tabular}{|c|c|c|c|c|c|}
\hline & $\begin{array}{c}\text { Kevlar® } \\
\text { Cord }\end{array}$ & $\begin{array}{c}\text { Kevlar }{ }^{\circledR} \\
\text { Webbing }\end{array}$ & $\begin{array}{c}\text { Nylon } \\
\text { Broadcloth }\end{array}$ & $\begin{array}{c}\text { Nylon } \\
\text { Webbing }\end{array}$ & $\begin{array}{c}\text { Vectran }{ }^{\circledR} \\
\text { Cord }\end{array}$ \\
\hline Mineral Oil & & & & & \\
\hline $\begin{array}{c}\text { Mineral Oil- } \\
\text { EverBlum }\end{array}$ & & & & & \\
\hline Ink & $\mathrm{x}$ & $\mathrm{x}$ & & & $\mathrm{x}$ \\
\hline Ink-EverBlum & $\mathrm{x}$ & $\mathrm{x}$ & & & $\mathrm{x}$ \\
\hline Ink-Ink Thinner & $\mathrm{x}$ & $\mathrm{x}$ & & $\mathrm{x}$ & $\mathrm{x}$ \\
\hline Dirt & & & & $\mathrm{x}$ & $\mathrm{x}$ \\
\hline Dirt-Woolite ${ }^{\circledR}$ & & & & $\mathrm{x}$ & $\mathrm{x}$ \\
\hline Dirt-Dove ${ }^{8}$ & & & & $\mathrm{x}$ \\
\hline Dirt-Castile & & & & & $\mathrm{x}$ \\
\hline Basting Glue & & & & & $\mathrm{x}$ \\
\hline $\begin{array}{c}\text { Basting Glue- } \\
\text { Isopropyl Alcohol }\end{array}$ & & & & & \\
\hline Sergene & & & & & \\
\hline Sergene-Rag & & & & & \\
\hline
\end{tabular}

The re-tests were completed with the material specified in Table 1. The sample preparation and test set-up detailed in Section II.D and Section II.E were used to complete the tests, with two major exceptions:

1. The number of samples was increased from 5 to 10.

2. The samples were cleaned less vigorously than done during the initial testing; this was to reduce the likelihood of damaging the material through the application of the cleaning agent.

Kevlar® cord contaminated with Sergene and cleaned with a rag was not re-tested, although the mean efficiency values were $95 \%$ and $93 \%$, respectively. This is believed to have been contributed to by the relatively low value of one of the samples (compared to the average). 


\section{Final Results (with Re-Tests)}

\section{A. Strength Degradation}

The original tests were completed with 5 controls, 5 contaminated samples, and 5 contaminated-then-cleaned samples. For the re-tests, each sample set consisted of 10 controls, 10 contaminated samples, and 10 contaminatedthen-cleaned samples. For each sample set, two sets of efficiencies were calculated: one set to compare the controls to the contaminated samples and another set to compare the controls to the contaminated-then-cleaned samples. Within each set of efficiencies, both the mean and standard efficiencies were calculated; see Section III.A and Equations 1-2.

Table 14 below gives the mean efficiencies for all of the tests. The re-tests are highlighted in yellow, and the initial results are included in parentheses. Those tests that resulted in mean efficiencies less than $95 \%$ are highlighted in red:

Table 14. Mean Efficiencies, Final Results

\begin{tabular}{|c|c|c|c|c|c|}
\hline & $\begin{array}{c}\text { Kevlar® } \\
\text { Cord }\end{array}$ & $\begin{array}{c}\text { Kevlar® } \\
\text { Webbing }\end{array}$ & $\begin{array}{c}\text { Nylon } \\
\text { Broadcloth }\end{array}$ & $\begin{array}{c}\text { Nylon } \\
\text { Webbing }\end{array}$ & $\begin{array}{c}\text { Vectran }{ }^{\circledR} \\
\text { Cord }\end{array}$ \\
\hline Mineral Oil & $100 \%$ & $98 \%$ & $101 \%$ & $97 \%$ & $100 \%$ \\
\hline $\begin{array}{c}\text { Mineral Oil- } \\
\text { EverBlum }\end{array}$ & $99 \%$ & $101 \%$ & $101 \%$ & $98 \%$ & $101 \%$ \\
\hline Ink & $99 \%(96 \%)$ & $101 \%(101 \%)$ & $104 \%$ & $98 \%$ & $99 \%(93 \%)$ \\
\hline Ink-EverBlum & $99 \%(94 \%)$ & $102 \%(94 \%)$ & $101 \%$ & $100 \%$ & $96 \%(95 \%)$ \\
\hline Ink-Ink Thinner & $89 \%(91 \%)$ & $100 \%(90 \%)$ & $100 \%$ & $99 \%$ & $99 \%(97 \%)$ \\
\hline Dirt & $97 \%$ & $101 \%$ & $102 \%$ & $98 \%(98 \%)$ & $96 \%(93 \%)$ \\
\hline Dirt-Woolite ${ }^{\circledR}$ & $100 \%$ & $101 \%$ & $101 \%$ & $92 \%(92 \%)$ & $90 \%(98 \%)$ \\
\hline Dirt-Dove ${ }^{\circledR}$ & $95 \%$ & $100 \%$ & $98 \%$ & $86 \%(81 \%)$ & $96 \%(92 \%)$ \\
\hline Dirt-Castile & $98 \%$ & $102 \%$ & $98 \%$ & $84 \%(85 \%)$ & $94 \%(93 \%)$ \\
\hline Basting Glue & $101 \%$ & $97 \%$ & $103 \%$ & $102 \%$ & $99 \%(90 \%)$ \\
\hline $\begin{array}{c}\text { Basting Glue- } \\
\text { Isopropyl Alcohol }\end{array}$ & $97 \%$ & $96 \%$ & $104 \%$ & $100 \%$ & $97 \%(96 \%)$ \\
\hline Sergene & $95 \%$ & $102 \%$ & $103 \%$ & $99 \%$ & $99 \%$ \\
\hline Sergene-Rag & $93 \%$ & $98 \%$ & $101 \%$ & $101 \%$ & $99 \%$ \\
\hline
\end{tabular}

As stated in Section III.A, some mean efficiencies are slightly over $100 \%$. This signifies that there was no degradation to material strength after contamination, but the variation in breaking values within each set was wide enough to result in a sample average slightly greater than a control average.

As can be seen in Table 14, some of the results improved, while others still indicated strength degradation. These changes are discussed in Section VII. 
Table 15 below gives the standard efficiencies for all of the tests. The re-tests are highlighted in yellow, and the initial results are included in parentheses. These values are more conservative than the mean efficiencies and are not used to formulate the recommendations presented in this report:

Table 15. Standard Efficiencies, Final Results

\begin{tabular}{|c|c|c|c|c|c|}
\hline & $\begin{array}{c}\text { Kevlar }{ }^{\circledR} \\
\text { Cord }\end{array}$ & $\begin{array}{c}\text { Kevlar }{ }^{\circledR} \\
\text { Webbing }\end{array}$ & $\begin{array}{c}\text { Nylon } \\
\text { Broadcloth }\end{array}$ & $\begin{array}{c}\text { Nylon } \\
\text { Webbing }\end{array}$ & $\begin{array}{c}\text { Vectran }{ }^{\circledR} \\
\text { Cord }\end{array}$ \\
\hline Mineral Oil & $97 \%$ & $95 \%$ & $95 \%$ & $95 \%$ & $93 \%$ \\
\hline $\begin{array}{c}\text { Mineral Oil- } \\
\text { EverBlum }\end{array}$ & $97 \%$ & $98 \%$ & $99 \%$ & $96 \%$ & $98 \%$ \\
\hline Ink & $94 \%(94 \%)$ & $96 \%(97 \%)$ & $101 \%$ & $97 \%$ & $95 \%(83 \%)$ \\
\hline Ink-EverBlum & $95 \%(90 \%)$ & $98 \%(88 \%)$ & $100 \%$ & $100 \%$ & $93 \%(89 \%)$ \\
\hline Ink-Ink Thinner & $84 \%(87 \%)$ & $96 \%(83 \%)$ & $98 \%$ & $98 \%$ & $96 \%(93 \%)$ \\
\hline Dirt & $95 \%$ & $97 \%$ & $99 \%$ & $96 \%(94 \%)$ & $91 \%(83 \%)$ \\
\hline Dirt-Woolite ${ }^{\circledR}$ & $98 \%$ & $96 \%$ & $99 \%$ & $91 \%(90 \%)$ & $86 \%(94 \%)$ \\
\hline Dirt-Dove ${ }^{\circ}$ & $92 \%$ & $97 \%$ & $97 \%$ & $79 \%(77 \%)$ & $94 \%(86 \%)$ \\
\hline Dirt-Castile & $94 \%$ & $94 \%$ & $95 \%$ & $82 \%(84 \%)$ & $91 \%(85 \%)$ \\
\hline Basting Glue & $100 \%$ & $93 \%$ & $101 \%$ & $100 \%$ & $96 \%(80 \%)$ \\
\hline $\begin{array}{c}\text { Basting Glue- } \\
\text { Isopropyl Alcohol }\end{array}$ & $94 \%$ & $94 \%$ & $103 \%$ & $98 \%$ & $92 \%(88 \%)$ \\
\hline Sergene & $93 \%$ & $100 \%$ & $101 \%$ & $98 \%$ & $97 \%$ \\
\hline Sergene-Rag & $89 \%$ & $95 \%$ & $99 \%$ & $99 \%$ & $97 \%$ \\
\hline
\end{tabular}

Table 16 below shows the percent of samples that broke at the contamination. The re-tests are highlighted in yellow, and the initial results are included in parentheses.

Table 16. Percent of Samples that Broke at Contamination, Final Results

\begin{tabular}{|c|c|c|c|c|c|}
\hline & $\begin{array}{c}\text { Kevlar } \\
\text { Cord }\end{array}$ & $\begin{array}{c}\text { Kevlar } \\
\text { Webbing }\end{array}$ & $\begin{array}{c}\text { Nylon } \\
\text { Broadcloth }\end{array}$ & $\begin{array}{c}\text { Nylon } \\
\text { Webbing }\end{array}$ & $\begin{array}{c}\text { Vectran }{ }^{\circledR} \\
\text { Cord }\end{array}$ \\
\hline Mineral Oil & $20 \%$ & $20 \%$ & $0 \%$ & $0 \%$ & $0 \%$ \\
\hline $\begin{array}{c}\text { Mineral Oil- } \\
\text { EverBlum }\end{array}$ & $20 \%$ & $40 \%$ & $0 \%$ & $0 \%$ & $0 \%$ \\
\hline Ink & $70 \% /(0 \%)$ & $10 \% /(80 \%)$ & $0 \%$ & $20 \%$ & $40 \% /(20 \%)$ \\
\hline Ink-EverBlum & $70 \% /(80 \%)$ & $10 \% /(40 \%)$ & $60 \%$ & $20 \%$ & $30 \% /(0 \%)$ \\
\hline Ink-Ink Thinner & $100 \% /(80 \%)$ & $20 \% /(100 \%)$ & $40 \%$ & $40 \%$ & $50 \% /(20 \%)$ \\
\hline Dirt & $40 \%$ & $20 \%$ & $80 \%$ & $20 \% /(20 \%)$ & $40 \% /(0 \%)$ \\
\hline Dirt-Woolite ${ }^{\circledR}$ & $60 \%$ & $0 \%$ & $100 \%$ & $100 \% /(100 \%)$ & $50 \% /(0 \%)$ \\
\hline Dirt-Dove ${ }^{\circledR}$ & $100 \%$ & $60 \%$ & $60 \%$ & $100 \% /(100 \%)$ & $10 \% /(40 \%)$ \\
\hline Dirt-Castile & $100 \%$ & $0 \%$ & $60 \%$ & $100 \% /(100 \%)$ & $10 \% /(0 \%)$ \\
\hline Basting Glue & $0 \%$ & $20 \%$ & $0 \%$ & $0 \%$ & $0 \% /(0 \%)$ \\
\hline $\begin{array}{c}\text { Basting Glue- } \\
\text { Isopropyl Alcohol }\end{array}$ & $0 \%$ & $0 \%$ & $0 \%$ & $0 \%$ & $0 \% /(0 \%)$ \\
\hline Sergene & $100 \%$ & $60 \%$ & $40 \%$ & $0 \%$ & $40 \%$ \\
\hline Sergene-Rag & $80 \%$ & $20 \%$ & $0 \%$ & $20 \%$ & $0 \%$ \\
\hline
\end{tabular}


As stated in Section III.C., some of the efficiencies may have been low because only 5 controls and 5 samples were tested. Variability in strength within a single lot of material is possible, and the low number of samples may have resulted in artificially low efficiencies. The difference between the mean and standard efficiencies can be one indication of this; the closer this difference is to zero, the more consistent the breaking values were. To attempt to remove the effects of this phenomenon, 10 controls and 10 samples were tested during the re-tests. Table 17 below shows the difference between the mean and standard efficiencies, including the re-tests. The re-tests are highlighted in yellow, and the initial results are included in parentheses. Values higher than 5\% are highlighted in red:

Table 17. Difference in Mean and Standard Efficiencies, Final Results

\begin{tabular}{|c|c|c|c|c|c|}
\hline & $\begin{array}{c}\text { Kevlar } \\
\text { Cord }\end{array}$ & $\begin{array}{c}\text { Kevlar }{ }^{\circledR} \\
\text { Webbing }\end{array}$ & $\begin{array}{c}\text { Nylon } \\
\text { Broadcloth }\end{array}$ & $\begin{array}{c}\text { Nylon } \\
\text { Webbing }\end{array}$ & $\begin{array}{c}\text { Vectran } \\
\text { Cord }\end{array}$ \\
\hline Mineral Oil & $3 \%$ & $3 \%$ & $6 \%$ & $2 \%$ & $7 \%$ \\
\hline $\begin{array}{c}\text { Mineral Oil- } \\
\text { EverBlum }\end{array}$ & $2 \%$ & $3 \%$ & $2 \%$ & $2 \%$ & $3 \%$ \\
\hline Ink & $5 \%(2 \%)$ & $5 \%(4 \%)$ & $3 \%$ & $1 \%$ & $4 \%(10 \%)$ \\
\hline Ink-EverBlum & $4 \%(4 \%)$ & $4 \%(6 \%)$ & $1 \%$ & $0 \%$ & $3 \%(6 \%)$ \\
\hline Ink-Ink Thinner & $5 \%(4 \%)$ & $4 \%(7 \%)$ & $2 \%$ & $1 \%$ & $3 \%(4 \%)$ \\
\hline Dirt & $2 \%$ & $4 \%$ & $3 \%$ & $2 \%(4 \%)$ & $5 \%(10 \%)$ \\
\hline Dirt-Woolite ${ }^{\circledR}$ & $2 \%$ & $5 \%$ & $2 \%$ & $1 \%(2 \%)$ & $4 \%(4 \%)$ \\
\hline Dirt-Dove ${ }^{\circledR}$ & $3 \%$ & $3 \%$ & $1 \%$ & $7 \%(4 \%)$ & $2 \%(6 \%)$ \\
\hline Dirt-Castile & $4 \%$ & $8 \%$ & $3 \%$ & $2 \%(1 \%)$ & $3 \%(8 \%)$ \\
\hline Basting Glue & $1 \%$ & $4 \%$ & $2 \%$ & $2 \%$ & $3 \%(10 \%)$ \\
\hline $\begin{array}{c}\text { Basting Glue- } \\
\text { Isopropyl Alcohol }\end{array}$ & $3 \%$ & $2 \%$ & $1 \%$ & $2 \%$ & $5 \%(8 \%)$ \\
\hline Sergene & $2 \%$ & $2 \%$ & $2 \%$ & $1 \%$ & $2 \%$ \\
\hline Sergene-Rag & $4 \%$ & $3 \%$ & $2 \%$ & $2 \%$ & $2 \%$ \\
\hline Average & $3.1 \%$ & $3.8 \%$ & $2.3 \%$ & $1.9 \%$ & $3.5 \%$ \\
$(2.8 \%)$ & $(4.2 \%)$ & $(2.3 \%)$ & $(1.8 \%)$ & $(6.2 \%)$ \\
\hline
\end{tabular}

As can be seen from the above testing data, the precision of the Vectran ${ }^{\circledR}$ cord breaking strengths improved by about $2.5 \%$. Although only a few re-tests were completed with Kevlar® and Nylon, results suggest that $3 \%$ and $2 \%$, respectively, remain the normal variation within those materials. Therefore, this data indicates that a higher number of controls and samples is required when testing Vectran ${ }^{\circledR}$ cord; if only 5 controls and samples are used, there is a chance that the spread of breaking strength values could have a detrimental (and misleading) effect on the overall strength. While not as critical as with Vectran ${ }^{\circledR}$, it is also recommended to have at least 10 samples with $\operatorname{Kevlar}{ }^{\circledR}$ and Nylon. 


\section{B. Appearances of Material after Cleaning}

The appearance of materials after the application of cleaning agents can be categorized in one of three ways:

1. All or most of the contamination appeared to have been removed, returning the sample to its original state.

2. Some of the contaminant was removed, but the contaminated area was still noticeable.

3. Little to none of the contaminant was able to be removed.

The appearance of each sample after cleaning depends on material type, contaminant applied, and cleaning agent used. Table 18 through Table 22 give representative photos of each sample after cleaning and classifies the appearance of the material using the above categories. While this classification is ultimately not as important as any actual strength degradation, it is still an important factor when selecting cleaning agents. For the samples sets that warranted a re-test, images from both the initial test and re-test are included.

Table 18. Appearance of Kevlar ${ }^{\circledR}$ Cord after Cleaning

\begin{tabular}{|c|c|c|}
\hline & Classification & Representative Photo \\
\hline Control & N/A & \\
\hline $\begin{array}{l}\text { Mineral Oil- } \\
\text { EverBlum }\end{array}$ & 1 & 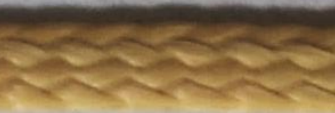 \\
\hline $\begin{array}{c}\text { Ink- } \\
\text { EverBlum, } \\
\text { Initial Test }\end{array}$ & 3 & \\
\hline $\begin{array}{c}\text { Ink- } \\
\text { EverBlum, } \\
\text { Re-Test }\end{array}$ & 3 & \\
\hline $\begin{array}{c}\text { Ink-Ink } \\
\text { Thinner, } \\
\text { Initial Test }\end{array}$ & 3 & \\
\hline $\begin{array}{c}\text { Ink-Ink } \\
\text { Thinner, Re- } \\
\text { Test }\end{array}$ & 3 & \\
\hline
\end{tabular}




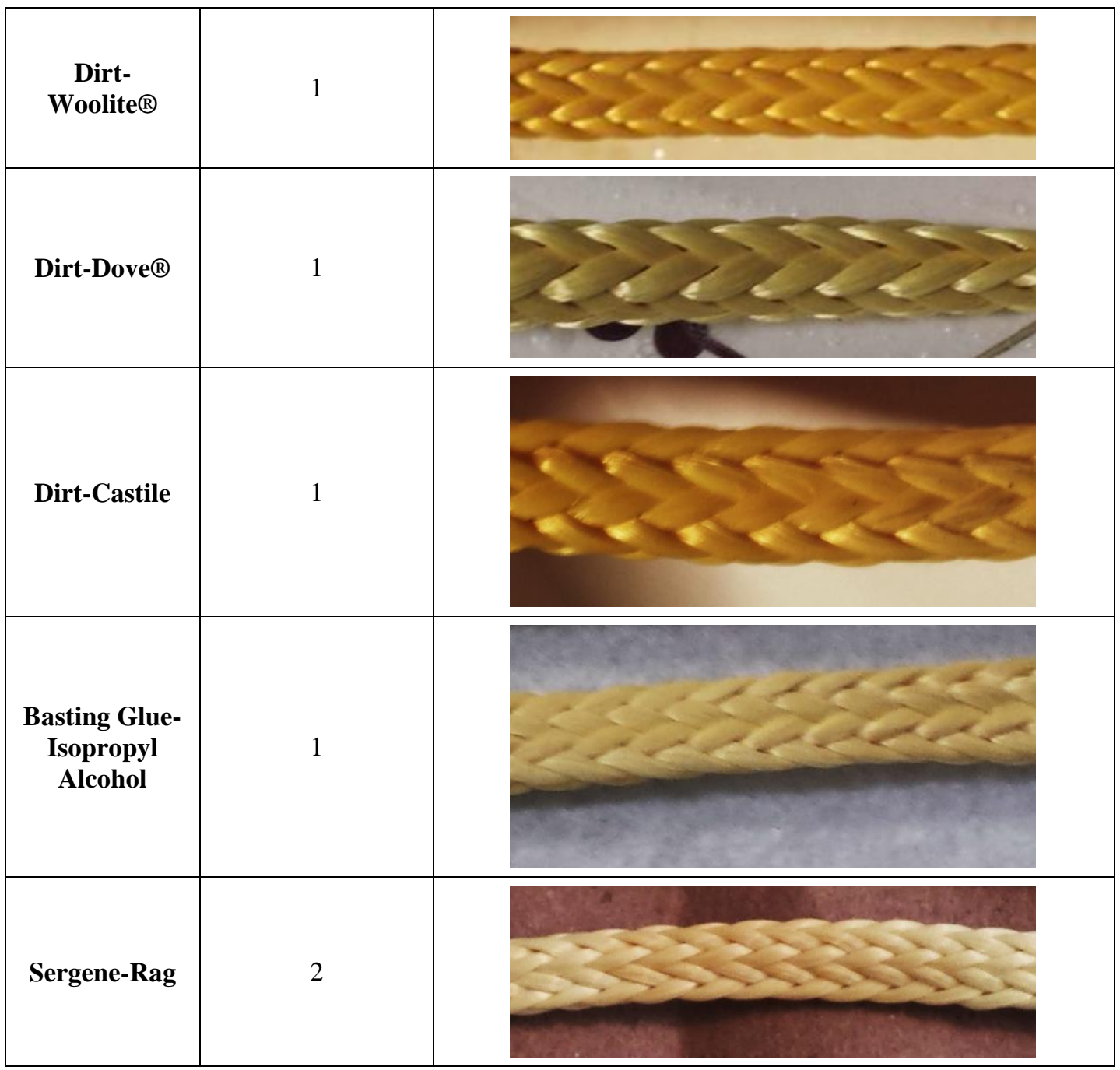


Table 19. Appearance of Kevlar ${ }^{\circledR}$ Webbing After Cleaning

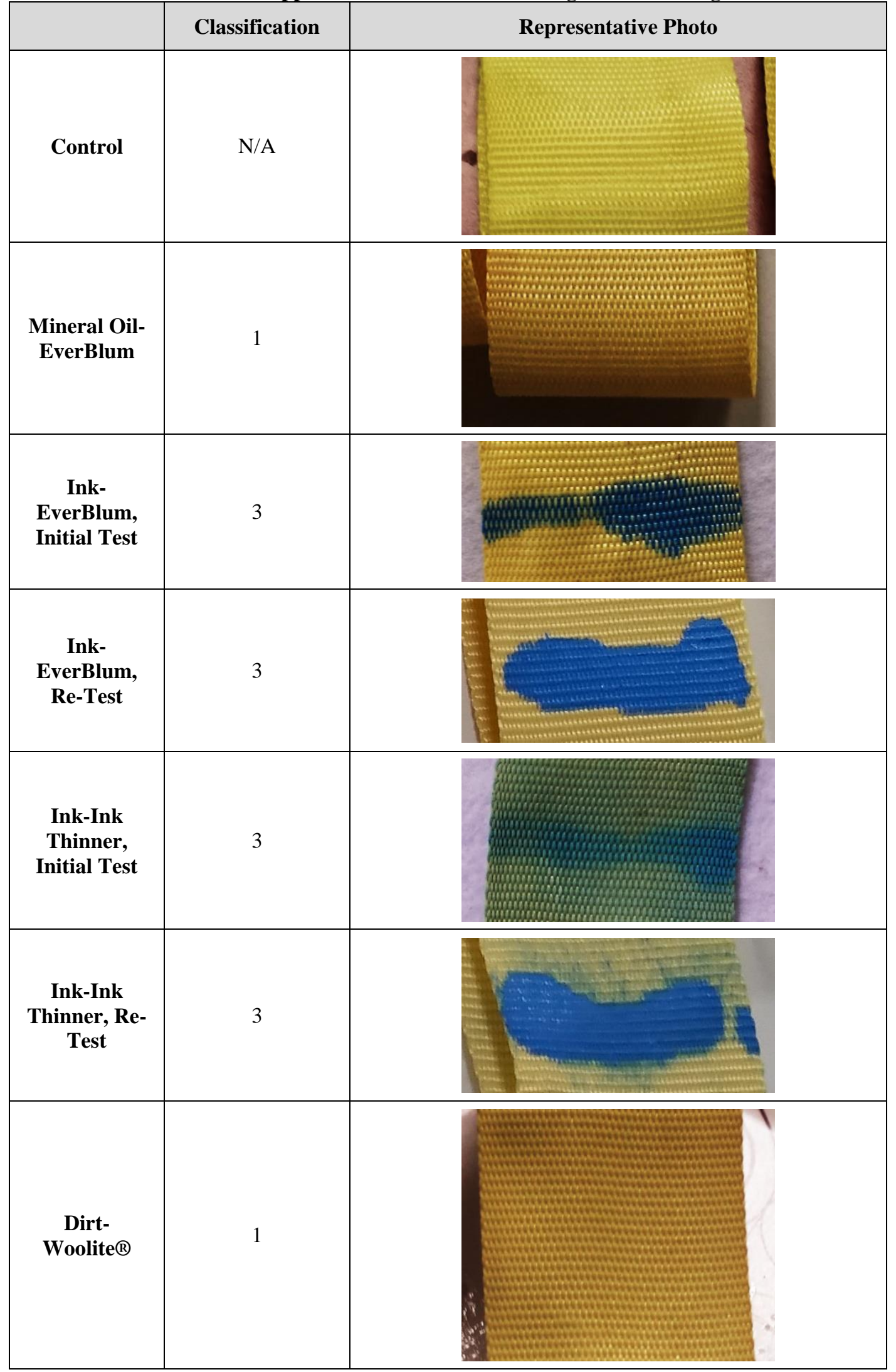




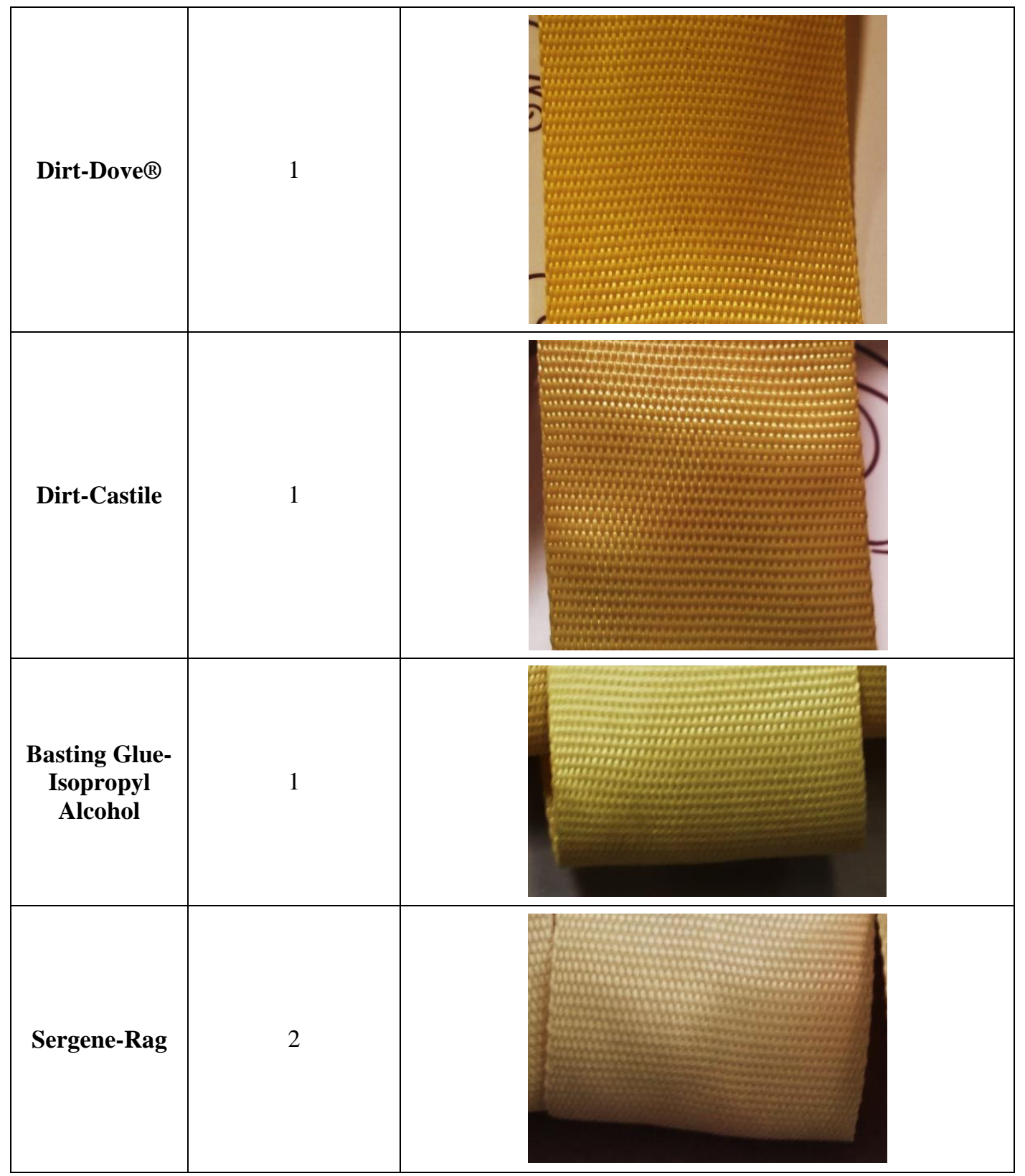


Table 20. Appearance of Nylon Broadcloth after Cleaning

\begin{tabular}{|c|c|c|}
\hline & Classification & Representative Photo \\
\hline Control & N/A & \\
\hline $\begin{array}{l}\text { Mineral Oil- } \\
\text { EverBlum }\end{array}$ & 1 & \\
\hline $\begin{array}{c}\text { Ink- } \\
\text { EverBlum }\end{array}$ & 3 & \\
\hline $\begin{array}{l}\text { Ink-Ink } \\
\text { Thinner }\end{array}$ & 1 & \\
\hline $\begin{array}{c}\text { Dirt- } \\
\text { Woolite }{ }^{\circledR}\end{array}$ & 1 & \\
\hline Dirt-Dove ${ }^{\circledR}$ & 1 & \\
\hline Dirt-Castile & 1 & \\
\hline
\end{tabular}




\begin{tabular}{|c|c|c|}
\hline $\begin{array}{c}\text { Basting Glue- } \\
\text { Isopropyl } \\
\text { Alcohol }\end{array}$ & 1 & \\
\hline & & \\
Sergene-Rag & 2 & \\
& & \\
\hline
\end{tabular}

Table 21. Appearance of Nylon Webbing after Cleaning

\begin{tabular}{|c|c|c|}
\hline & Classification & Representative Photo \\
\hline Control & N/A & \\
\hline $\begin{array}{c}\text { Mineral Oil- } \\
\text { EverBlum }\end{array}$ & 1 & \\
\hline $\begin{array}{c}\text { Ink- } \\
\text { EverBlum }\end{array}$ & 3 & \\
\hline $\begin{array}{c}\text { Ink-Ink } \\
\text { Thinner }\end{array}$ & 3 & \\
\hline $\begin{array}{c}\text { Woolite®, } \\
\text { Initial Test }\end{array}$ & 2 & \\
\hline
\end{tabular}




\begin{tabular}{|c|c|}
\hline $\begin{array}{c}\text { Dirt- } \\
\text { Woolite } \AA, \\
\text { Re-Test }\end{array}$ & 2 \\
\hline $\begin{array}{c}\text { Dirt-Dove®, } \\
\text { Initial Test }\end{array}$ & 2 \\
\hline $\begin{array}{c}\text { Dirt-Dove®, } \\
\text { Re-Test }\end{array}$ & 2 \\
\hline $\begin{array}{l}\text { Dirt-Castile, } \\
\text { Initial Test }\end{array}$ & 2 \\
\hline $\begin{array}{c}\text { Dirt-Castile, } \\
\text { Retest }\end{array}$ & 2 \\
\hline $\begin{array}{l}\text { Basting Glue- } \\
\text { Isopropyl } \\
\text { Alcohol }\end{array}$ & 1 \\
\hline Sergene-Rag & 2 \\
\hline
\end{tabular}


Table 22. Appearance of Vectran ${ }^{\circledR}$ Cord after Cleaning

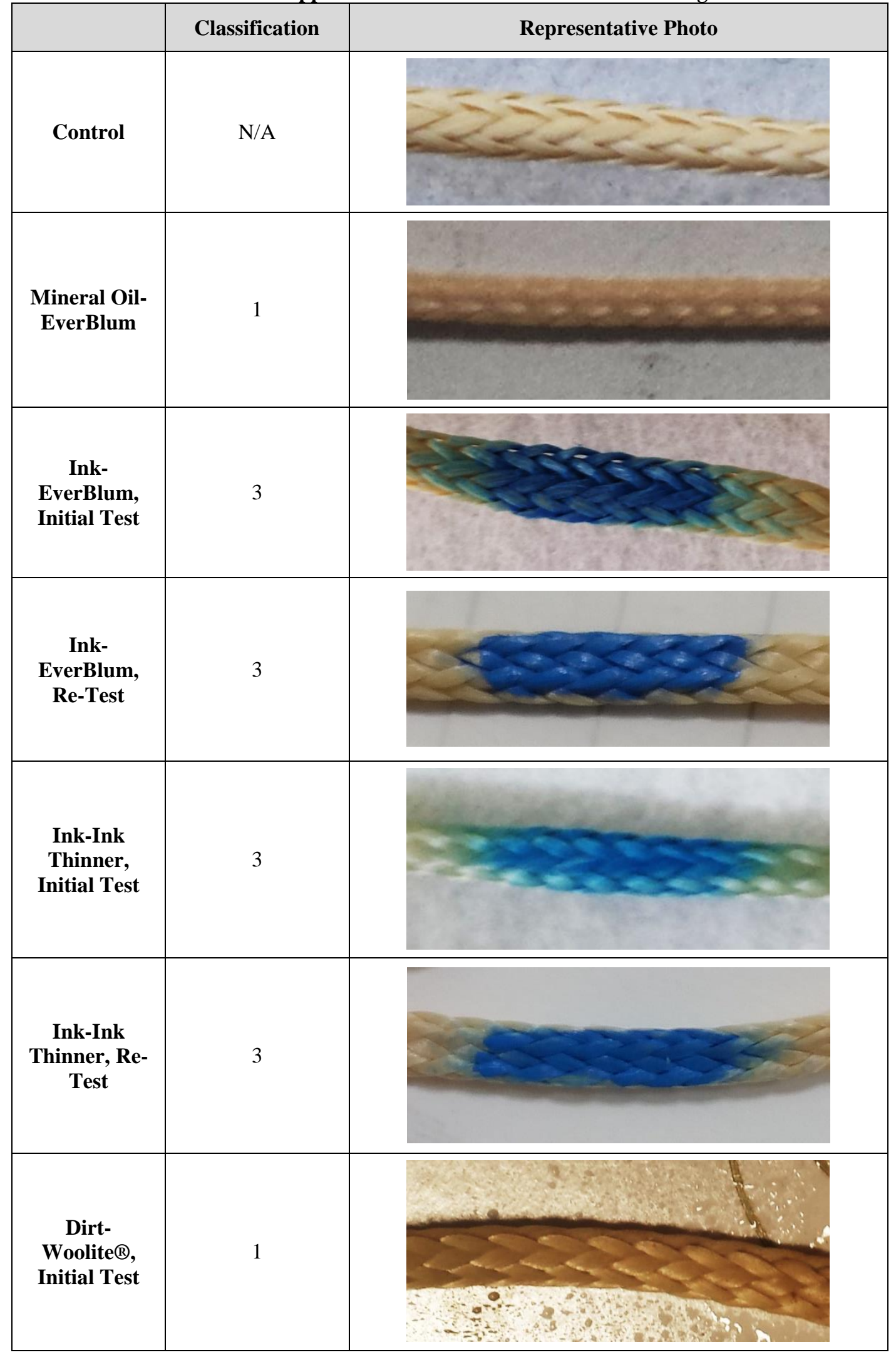




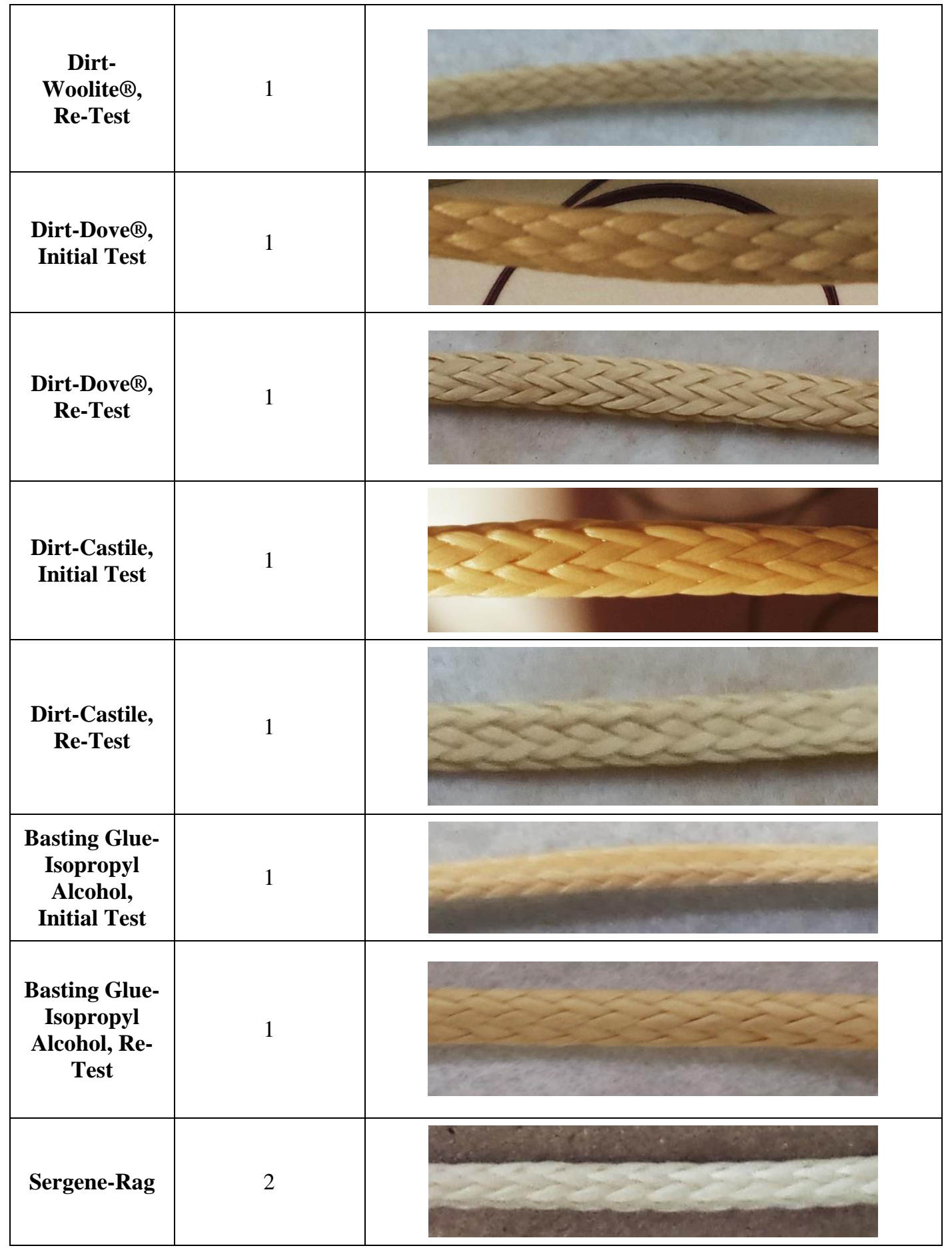




\section{Effects of Rust on Nylon Broadcloth}

\section{A. Introduction}

During the cleaning and repair process of a couple of large ringsail parachutes, sections of Nylon broadcloth were contaminated with rust. A testing program was developed to quantify any strength degradation effects and identify a possible cleaning process. The goal was to determine the necessary cleaning or repair process, if required.

\section{B. Test Program}

12 total samples were taken from a single parachute. They were cut from the white panels in Ring 4/Sails 1-5, all of which were from the same lot of material. The samples were cut to a 36 " length and unraveled to a 1.50-2.00" width (depending on the available width of the cut sample). Of the 12 samples, 4 had no rust contamination. The other 8 were chosen to have a significant amount of rust near the middle of the sample. See Figure 22 and Figure 21:

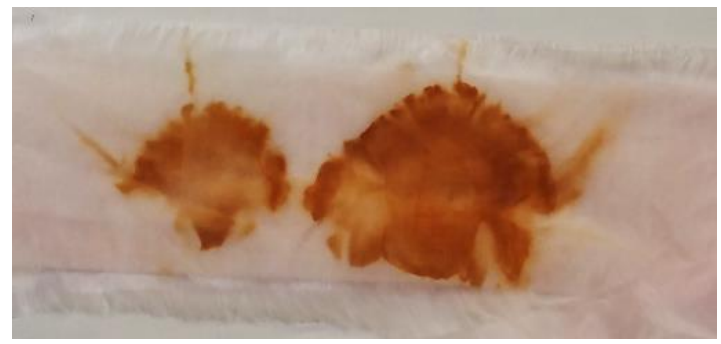

Figure 22. Example 1 of Rust-Contaminated Sample

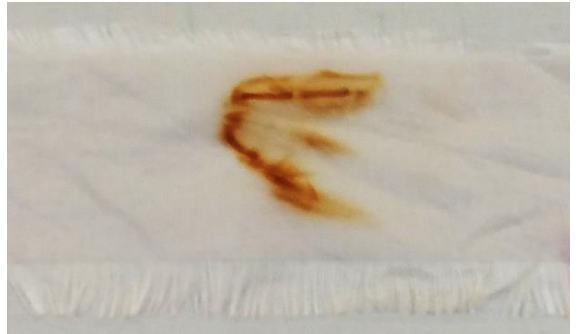

Figure 21. Example 2 of Rust-Contaminated Sample

4 of the 8 rust-contaminated samples were then cleaned. Based on anecdotal and internet research, a solution of commercially-available lemon juice and table salt was mixed to a "slushy" consistency and applied to the rusted sections. The samples were them placed outside under direct sunlight for several hours. This process produced samples with little to no trace of rust when the solution was washed off with water. See Figure 24 and Figure 25:

The samples were then set-up and tested as detailed in Section II.E.4. See Figure 23:

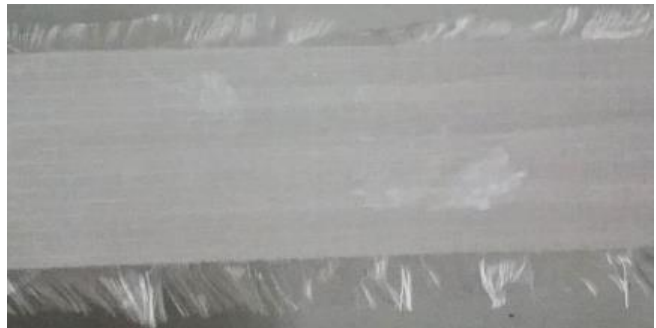

Figure 24. Example 1 of Cleaned Sample

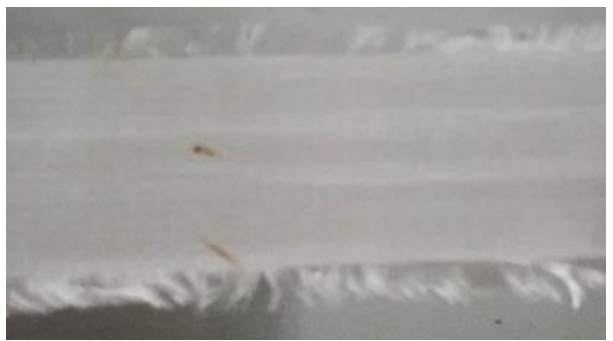

Figure 25. Example 2 of Cleaned Sample

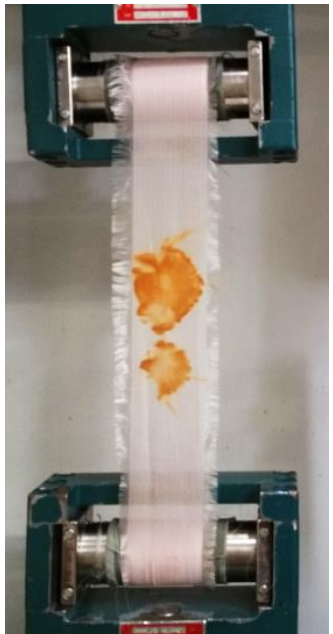

Figure 23. Test Set-Up 


\section{Test Results}

Table 23 gives the results for the testing program. Based on the material specification (Airborne specification 05QR4-820200), the minimum adequate strength at the time of material acceptance was $45 \mathrm{lbf} / \mathrm{in}$. The mean and standard efficiencies were calculated using Equations 1 and 2.

Table 23. Test Results for Rust-Contamination Study

\begin{tabular}{|c|c|c|c|}
\hline \multicolumn{2}{|c|}{ Sample } & $\begin{array}{c}\text { Breaking } \\
\text { Strength (lbf/in) }\end{array}$ & Breaking Location \\
\hline \multirow{6}{*}{ Controls } & $\mathrm{C} 1$ & 48.3 & \\
\hline & $\mathrm{C} 2$ & 44.9 & \\
\hline & $\mathrm{C} 3$ & 47.6 & \\
\hline & $\mathrm{C} 4$ & 48.6 & \\
\hline & Average & 47.4 & \\
\hline & Standard Deviation & 1.7 & \\
\hline \multirow{8}{*}{ Contaminated } & S1 & 47.3 & Not at contamination \\
\hline & S2 & 46.2 & At contamination \\
\hline & S3 & 48.2 & Near contamination \\
\hline & S4 & 47.8 & Near contamination \\
\hline & Average & 47.4 & \\
\hline & Standard Deviation & 0.9 & \\
\hline & Mean Efficiency & $100.0 \%$ & \\
\hline & Standard Deviation & $98.2 \%$ & \\
\hline \multirow{8}{*}{$\begin{array}{l}\text { Contaminated } \\
\text { then Cleaned }\end{array}$} & S5 & 36.0 & Near middle \\
\hline & S6 & 34.6 & Not at middle \\
\hline & S7 & 38.1 & In middle \\
\hline & S8 & 35.1 & Near middle \\
\hline & Average & 35.9 & \\
\hline & Standard Deviation & 1.6 & \\
\hline & Mean Efficiency & $75.9 \%$ & \\
\hline & Standard Deviation & $72.6 \%$ & \\
\hline
\end{tabular}

The analysis of results and recommendation are given in conjunction with the results of the complete contamination study. See Section VII.F. 


\section{Analysis of Results and Recommendations}

The following sections provide recommendations for cleaning (or not cleaning) each of the contaminants from each of the material types. These recommendations are derived from:

1. The strength degradation, as quantified by the mean efficiencies (Table 14 and Table 23)

2. The breaking location of the test samples (Table 16 and Table 23)

3. The effectiveness of the cleaning agent at removing the contamination, based on appearance (Table 18 to Table 22)

Although the test data can be used to formulate cleaning recommendations, this test data should not be used to apply formal degradation factors to structural components. This is due to the following reasons:

- Only 5 controls and 5 samples were used to calculate the efficiencies for the majority of the sample sets. (On CPAS, the formal joint efficiency is calculated with 5 controls and 10 samples.)

- Although care was taken to apply the contaminants and cleaning agents in an identical manner within each of the sample sets, there were some inherent differences in the amount used or method applied.

- Outliers are included in the efficiency calculations, although they may be skewing the efficiencies either slightly high or low.

- On some occasions, the controls and samples were tested on different days under different conditions, although the same test setup was implemented.

\section{A. Contamination by Mineral Oil}

All five material types experienced no degradation upon application of the mineral oil or after being cleaned with EverBlum. Therefore, if the contaminated area is small, the mineral oil does not need to be removed. If the contaminated area is large or if there is a requirement to remove it, the contaminated area may be cleaned with EverBlum.

\section{B. Contamination by Ink}

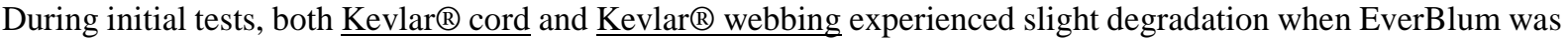
used to remove dried ink; greater strength loss was seen when ink thinner was used. During the re-tests, more care was taken to not scrub hard enough to damage the material (as may have happened in the initial tests); when these samples were pulled to failure, only Kevlar ${ }^{\circledR}$ cord cleaned with ink thinner still experienced strength degradation. The images in Table 18 and Table 19 show that neither EverBlum nor ink thinner were effective in removing dried ink from Kevlar ${ }^{\circledR}$ cord or webbing either with hard scrubbing pressure (initial tests) or light scrubbing pressure (re-tests). Therefore, no cleaning is recommended to remove dried ink from either Kevlar ${ }^{\circledR}$ cord or webbing.

For Nylon broadcloth and Nylon webbing, no degradation was seen upon application of ink or after being cleaned by EverBlum or ink thinner. Only ink thinner was effective in removing ink from Nylon broadcloth, as seen in Table 20. However, as seen in Table 21, neither cleaning agent was effective in removing the contaminant from Nylon webbing. Therefore, cleaning with ink thinner is recommended for Nylon broadcloth (although not required) and no cleaning is recommended for Nylon webbing.

During initial tests, $\underline{\text { Vectran }}{ }^{\circledR}$ cord experienced minor strength loss upon application of ink. This strength loss was slightly mitigated with the use of either EverBlum or ink thinner, although neither cleaning agent was effective in visually removing the contamination (see Table 22). The re-tests showed that the results of the initial tests may not be entirely valid - when the tests were repeated with more samples, there was no strength degradation experienced by the presence of dried ink. Therefore, no cleaning is recommended for Vectran® cord when contaminated with dried ink.

\section{Contamination by Dirt}

Kevlar® cord, Kevlar® webbing, and Nylon broadcloth experienced no degradation due to dirt or to being later cleaned with Woolite ${ }^{\circledR}$, Dove ${ }^{\circledR}$ soap, or Castile soap. Table 18, Table 19, and Table 20 show that all three cleaning agents were effective at removing contamination from all three materials. Therefore, if dirt is present on any of these three material types, the dirt can be left or it can be removed with any of the three tested cleaning products.

Nylon webbing, during initial tests, experienced no strength degradation due to dirt; when cleaned with Woolite ${ }^{\circledR}$, Dove ${ }^{\circledR}$ soap, or Castile soap, there was a minor loss in strength. The re-tests showed the same results, with degradation values from $80-90 \%$. During the re-tests, care was taken not to scrub the materials as hard as may have occurred during the initial tests, yet similar strength degradation was experienced. Based on these results, it is recommended to not use any of these three cleaning products on Nylon webbing contaminated by dirt. 
Vectran ${ }^{\circledR}$ cord, like Nylon webbing, saw a variation in strength loss during initial testing upon application of dirt and the three cleaning products. Samples then cleaned with Woolite ${ }^{\circledR}$ regained their strength, while those cleaned with Dove ${ }^{\circledR}$ and Castile soaps remained degraded. For the re-tests, the results were slightly different; while samples contaminated with dirt and those later cleaned with Dove ${ }^{\circledR}$ soap experienced little to no degradation, those cleaned with Woolite ${ }^{\circledR}$ and Castile soaps experienced degradation from 90-94\%. These results may still be based on the strength variation inherent in Vectran ${ }^{\circledR}$ cord itself, but caution is recommended when cleaning dirt from Vectran ${ }^{\circledR}$ cord.

\section{Contamination by Basting Glue}

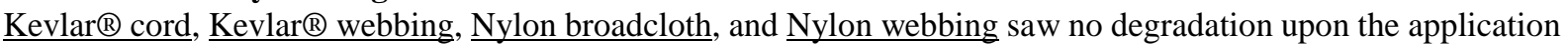
or removal of basting glue. Therefore, it is recommended to carefully remove any excess basting glue on these materials without damaging any of the fibers. Further cleaning with isopropyl alcohol is not necessary, although it will not degrade the material.

During initial testing, $\underline{\text { Vectran }}$ cord experienced minor degradation from the application of basting glue. This degradation was reduced by removing the basting glue and using isopropyl alcohol to clean the affected area. The retests showed that this loss in strength is most likely not genuine; there was no strength degradation experienced by the Vectran ${ }^{\circledR}$ cord either after application of basting glue or after its removal. Therefore, it is recommended to remove any unwanted basting glue from Vectran ${ }^{\circledR}$ cord either with or without the aid of isopropyl alcohol.

\section{E. Contamination by Sergene}

All five material types experienced no degradation upon application of Sergene. After being cleaned with a rag, only Kevlar® cord experienced a mean efficiency lower than 95\%, although this was most likely contributed to by the relatively low value of one of the samples. Therefore, it is recommended that if excess Sergene is accidentally applied to one of the five material types used as a structural element on CPAS, a lint-free rag (or equivalent) should be used to soak up as much Sergene as possible, with limited rubbing of the material. Once the Sergene is dry, the material may be manipulated to regain flexibility.

\section{F. Contamination by Rust}

Only Nylon broadcloth was tested with respect to rust contamination. The sections of broadcloth with rust on them, when compared with uncontaminated areas, experienced no degradation in strength. While the cleaning process of lemon juice, salt, and direct sunlight completely eliminated the appearance of any rust, the strength was degraded by approximately $25 \%$. Also, sunlight is known to be damaging to Kevlar ${ }^{\circledR}$, which may be near the Nylon broadcloth on an actual parachute. Therefore, it is recommended to not clean the rusted areas on Nylon broadcloth. If a clean appearance is still sought, it is recommended to replace the sections or panels entirely.

The effects of rust on other textile types and materials was not studied here. Further testing is required to access the effects of rust on Nylon webbing, Kevlar ${ }^{\circledR}$ cord and webbing, and Vectran ${ }^{\circledR}$ cord. 


\section{G. Summary of Recommendations}

Table 24 below summarizes the recommendations from Section IV.A to Section IV.F. These recommendations apply to Kevlar $\circledR^{\circledR}$ cord and webbing, Nylon broadcloth and webbing, and Vectran ${ }^{\circledR}$ cord for the stated contaminants. As a key, the following phrases are defined:

- "Do not clean" = strength degradation may occur

- "No cleaning necessary" = no strength degradation will occur, but the cleaning method may not be effective

Table 24. Summary of Cleaning Recommendations

\begin{tabular}{|c|c|}
\hline Contaminant & Recommendation \\
\hline Mineral Oil & $\begin{array}{l}\text { - No cleaning necessary. If contaminated area is large or cleaning is required, clean } \\
\text { with EverBlum. }\end{array}$ \\
\hline Ink & $\begin{array}{l}\text { - For Kevlar® cord and webbing, do not clean. } \\
\text { - For Nylon broadcloth, no cleaning necessary. If required, clean with ink thinner. } \\
\text { - For Nylon webbing, no cleaning necessary. } \\
\text { - For Vectran }{ }^{\circledR} \text { cord, no cleaning necessary. }\end{array}$ \\
\hline Dirt & $\begin{array}{l}\text { - For Kevlar® cord, Kevlar® webbing, and Nylon broadcloth, cleaning is not } \\
\text { necessary. If required, cleaning can be done with Woolite®, Dove® soap, or } \\
\text { Castile soap. } \\
\text { - For Nylon webbing, do not clean. } \\
\text { - For Vectran }{ }^{\circledR} \text { cord, do not clean. }\end{array}$ \\
\hline Basting Glue & $\begin{array}{l}\text { - For all materials, remove basting glue by hand. Isopropyl alcohol may be used to } \\
\text { remove any remaining glue, although it is not necessary. }\end{array}$ \\
\hline Sergene & $\begin{array}{l}\text { - Use lint-free rag or equivalent to soak up excess Sergene without rubbing or } \\
\text { scrubbing. Once material is dry, manipulate material to regain flexibility. }\end{array}$ \\
\hline Rust & $\begin{array}{l}\text { - For Nylon broadcloth, do not clean. For appearance’s sake, contaminated } \\
\text { sections or entire panels can be replaced. } \\
\text { - No recommendations for Nylon webbing, Kevlar® cord and webbing, and } \\
\text { Vectran® cord. Test these materials as-needed. }\end{array}$ \\
\hline
\end{tabular}

\section{H. Recommended Future Testing}

Although retests were completed, there are still a few results that need further study. Also, some additional tests are recommended. The list below details recommended tests to be completed in the future:

- Nylon webbing and Vectran ${ }^{\circledR}$ cord contaminated with dirt and cleaned with various cleaning agents: both the initial tests and retests showed the possibility of some strength degradation from the various cleaning methods. Because this seems unusual, it is recommended to repeat these tests again. More care should be taken to be consistent with dirt application and removal, and further variables could be added (such as using only water or trying other cleaning agents).

- $\quad$ Rust on other materials: testing was only completed on Nylon broadcloth. It is recommended to test rust contamination on other textile elements.

- Materials contaminated with wet ink: since dry ink was seen as a worst-case scenario, the ink on the samples was allowed to dry before removal was attempted. In many cases though, any mistakes in ink stamps are caught as soon as they happen (when the ink is wet).

- Other contaminants: there are many other contaminants that parachutes could come into contact to. This includes, but is not limited to: machine oil (such as that from hydraulic packing presses), permanent marker, and salt water. 


\section{Conclusion}

During the CPAS component inspection prior to EFT-1, 28 instances of sewing machine oil contamination were discovered on the main parachute Nylon broadcloth. The parachutes most likely came into contact with this contaminant during manufacturing. Besides these recordable incidences, contamination could also occur during packing, testing, storage, etc. In addition to Nylon broadcloth, contamination could occur to any of the materials that constitute a parachute and other related components, including the Kevlar® suspension lines (cord) and Kevlar® load radials (webbing).

In order to address the potential loss in strength from sewing machine oil and other contaminants, a study was conducted. A set of possible contaminants, along with potential cleaning agents for each, was formulated and obtained. The strength of the five materials that constitute the primary CPAS structural components (Kevlar cord®, $\operatorname{Kevlar}{ }^{\circledR}$ webbing, Nylon broadcloth, Nylon webbing, and Vectran ${ }^{\circledR}$ cord) was examined before contamination, after contamination, and after cleaning. The resulting strength degradations, paired with the actual effectiveness of each of the cleaning agents, were used to make recommendations for each of the scenarios. For those tests where the results were ambiguous or unanticipated, re-tests were completed with a greater number of samples. Some contaminants, like sewing machine oil (mineral oil), Sergene, and basting glue, caused little or no degradation to each of the material types. The application of other contaminants, such as ink, dirt, and the associated cleaning agents, resulted in an appreciable amount of strength loss for some of the base materials.

The results and recommendations detailed in this paper can be used when assessing the potential negative effects of contaminating a parachute, as well as when deciding whether or not to clean it. Further re-tests are also recommended, as well as the testing of different contaminants. The results of this study should also be examined with regards to outgassing requirements, to ensure that the recommended methods are allowed.

\section{Acknowledgments}

Many thanks to everyone who helped prepare and test the samples. With so many samples, any amount of aid was greatly appreciated.

\section{References}

${ }^{1}$ Mollmann, Catherine, "Strength Variation of Parachute Joints," AIAA 2017-XXXX, 2017 (to be published). 